
第第第第第第第第第音章 三款款款款款實實緒

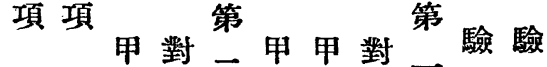

マ 牀照回腺腺照回成方

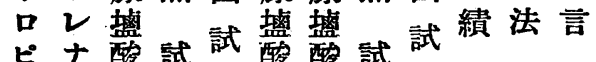
と酒驗酒酒驗

ノン精驗精精 驗

影 エ工殘工

龖影キ㴡キ

響 ス エ

試 $\neq$ 試

驗正 驗

試

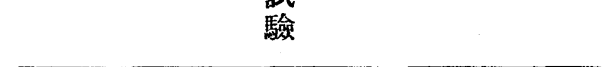

第第

五四

主 章章 第第第第第 第

要結總五四兰三款五四至

文括項項項項項 項項項 献 及゙ルアアア牀ルエア

並 ビルエアアアア狀ルエア

附論按ナゴチロレ堵ナご天

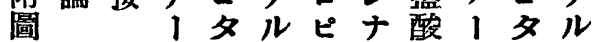
ルミヒンり酒ルミヒ ナンヨ,ン精ナンヨ 卜人门影, 殘卜, 》 り影ン激影渣り影ン ウ響, 響吕響,

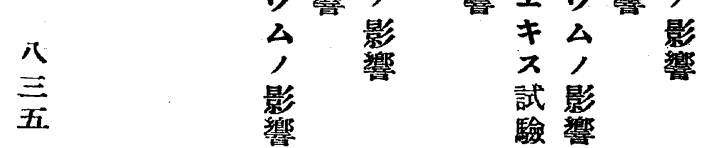

目

次

大
學
學 京
生 都
醫 國
學 大
土 學

中 學
中部

內

科

原

原 一。

堡
통

蝌 踣 出

並 腺

蚪二填

試 䎡发

二洒

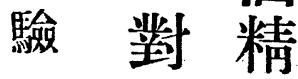

第 ス 越

一 自斯

報律 及

神 ビ

經 其

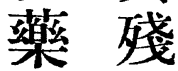

物 椬

) 1

景蜊

然畐

二 變

就 態

テ 二

及

ボ

ス

穗 
尹 研 ザ ダ シ 7 抑 資 該 こ(iv)

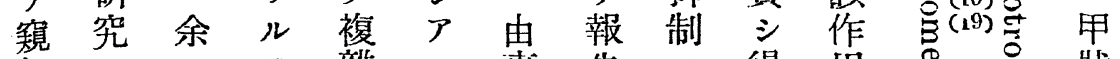

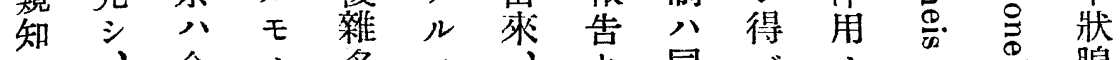
七、今, 多八、七同 $心$, 等 ン更回少岐明丽り濾キ極數》物 $卜=$ 三 $三$ 白 分 0 胞 $7 \times$ 多 ${ }^{(4)}$ 質

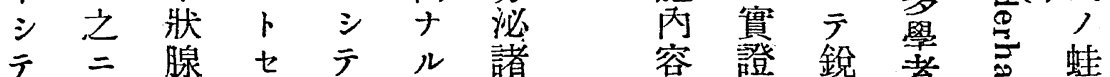
本對 物 ズ 向 事藏

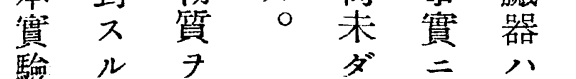

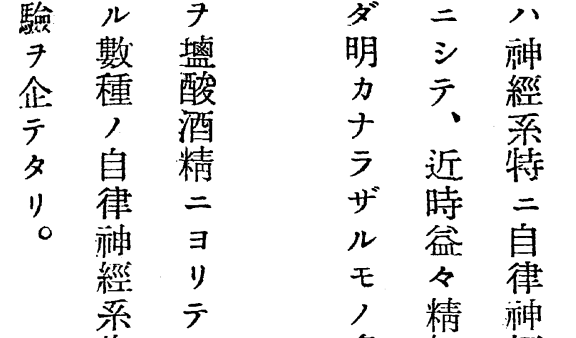
物 七 敏 者 总蝌 質り 具業导 蚪 ヨ 其 異 $\begin{array}{lll} \\ \text { ア 績 }\end{array}$ リ後ナ吋

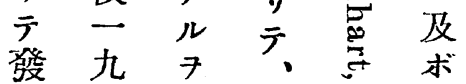
現 豆 以蛙 (7) ス ラ 年 作 エ 多細 經

用手蓕、な系

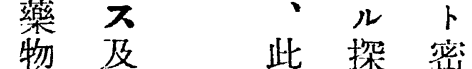

ノビ, 究接

影殘方二不

響 渣面依可

$7=$ リ 離

檢 分 業 テ ナ

シ 千 績 次ル

以最第 關

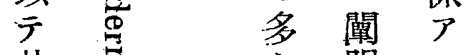

此昰明り

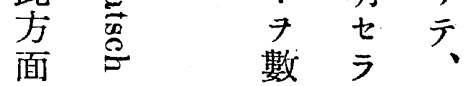

ヨ 氏

リ法 ル ツ 接

甲 7 甲、攵

狀用狀了分

腺 $七$ 腺归

帛雨 所 接

律物 キ

神質 テ モ互

橄

系生其之其

，物等, 闈,

渵的明 關能

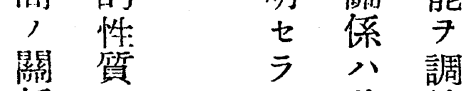

係 7 甚節

呚所蚪

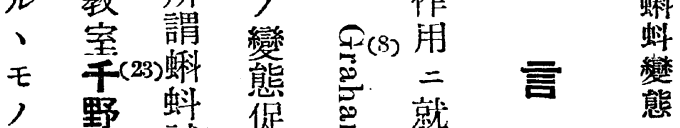

二野蚪促芯就

シ ビ 驗萑

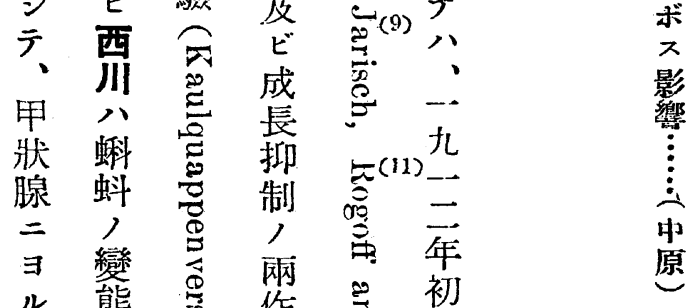

態兽㤰常初

蚪進导色占テ

變 甲

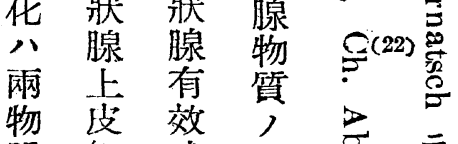

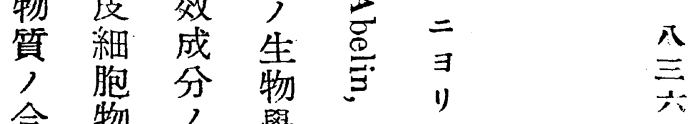

合質 證 學 的

作 争 明 特 邑 報

用 $\exists$ 业性 异

他り 效 三

ラ, 檢 テ、方

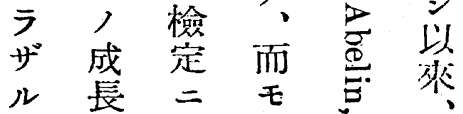




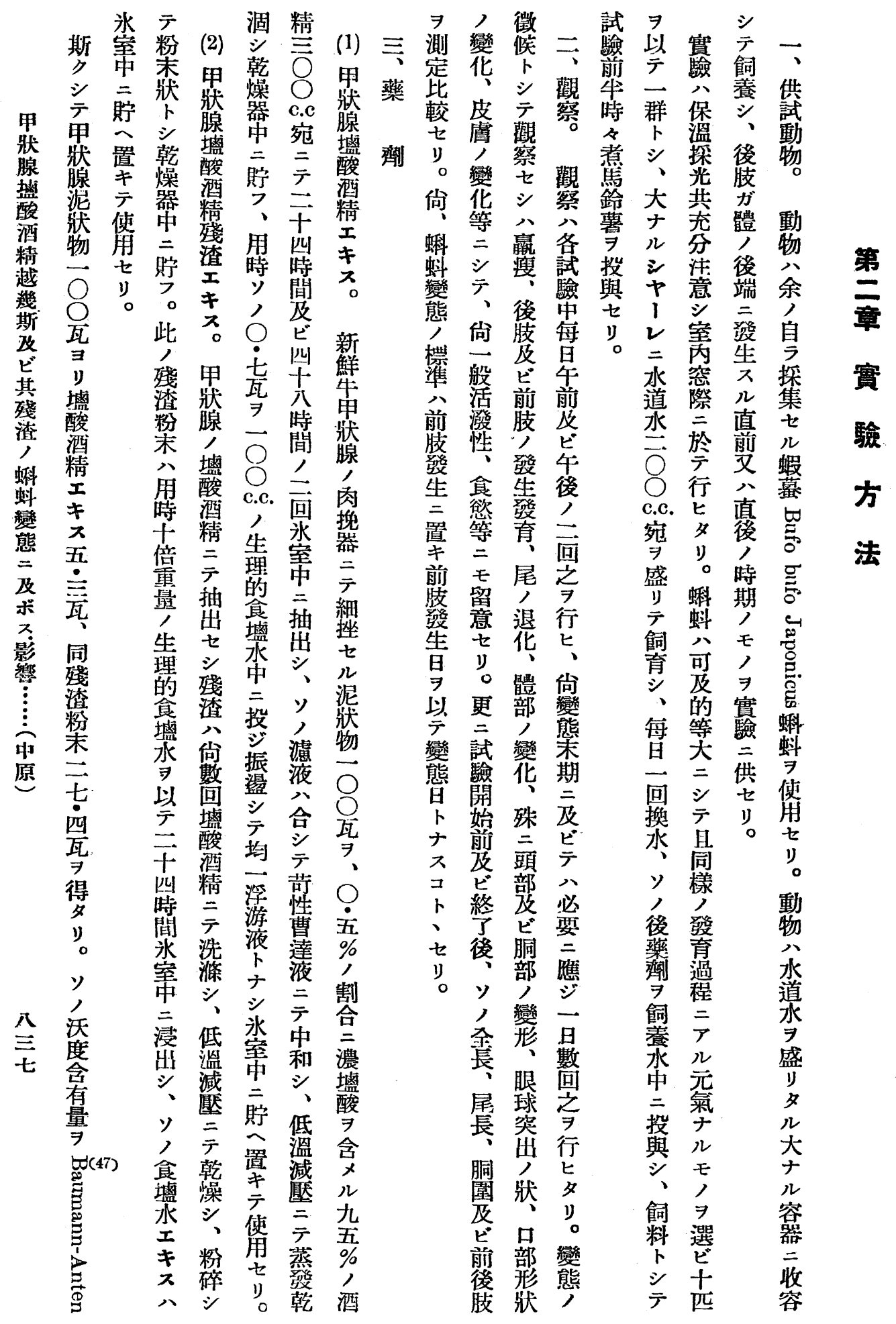




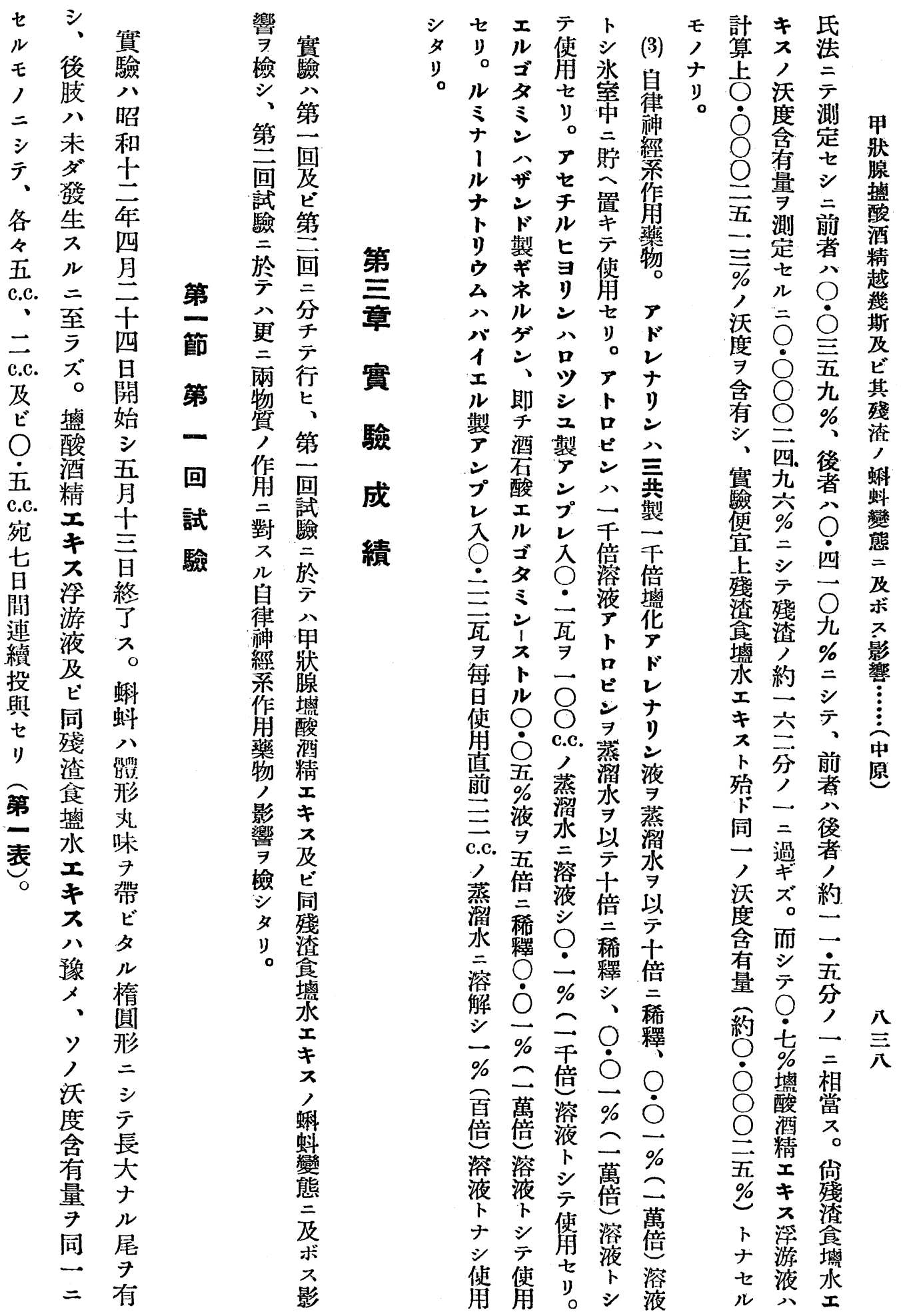


第一婁 第一回試驗藥劑投與量

\begin{tabular}{|c|c|c|c|c|c|c|c|c|}
\hline 實 & & 投 & \multicolumn{3}{|c|}{ 投與一日 量 } & \multicolumn{3}{|c|}{ 投 與 全 量 } \\
\hline $\begin{array}{l}\text { 驗 } \\
\text { 番 } \\
\text { 號 }\end{array}$ & $\begin{array}{l}\text { 與 } \\
\text { 物 } \\
\text { 質 }\end{array}$ & $\begin{array}{l}\text { 與 } \\
\text { 日 } \\
\text { 數 }\end{array}$ & $\begin{array}{l}\text { 投 } \\
\text { 與 } \\
\text { 液 } \\
\text { 量 } \\
\text { (站) } \\
\end{array}$ & $\begin{array}{l}\text { 含 } \\
\text { 有 } \\
\text { 原 } \\
\text { 料 } \\
\text { (浝) } \\
\end{array}$ & $\begin{array}{c}\text { 沃 } \\
\text { 度 } \\
\text { 含 } \\
\text { 有 } \\
\text { 量 } \\
\text { (毝) } \\
\end{array}$ & $\begin{array}{c}\text { 投 } \\
\text { 與 } \\
\text { 液 } \\
\text { 量 } \\
\text { (站) } \\
\end{array}$ & $\begin{array}{c}\text { 念 } \\
\text { 有 } \\
\text { 原 } \\
\text { 数 } \\
\text { (浝) } \\
\end{array}$ & $\begin{array}{c}\text { 沃 } \\
\text { 度 } \\
\text { 念 } \\
\text { 有 } \\
\text { 量 } \\
\text { (魀) } \\
\end{array}$ \\
\hline (0) $\mathrm{K}$ & （龆 照） & 0 & 0 & 0 & 0 & 0 & 0 & 0 \\
\hline (1) $\mathrm{EX}$ & $\begin{array}{l}\text { 甲狀腺 揊酸 } \\
\text { 酒精エキス浮游液 }\end{array}$ & 7 & 5.0 & 35 & 0.0125 & 35 & 245 & 0.0875 \\
\hline (2) $\mathrm{Ex}$ & 上 & 7 & 2.0 & 14 & 0.0050 & 14 & 98 & 0.0350 \\
\hline (3) eX & 上 & 7 & 0.5 & 3.5 & 0.00125 & 3.5 & 24.5 & 0.00875 \\
\hline (4) $\mathrm{RS}$ & 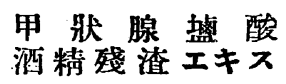 & 7 & 5.0 & 500 & 0.0125 & 35 & 3500 & 0.0875 \\
\hline (5) $\mathrm{Rs}$ & 同 & 7 & 2.0 & 200 & 0.0050 & 14 & 1400 & 0.0350 \\
\hline (6) $\mathrm{rS}$ & 同 & 7 & 0.5 & 50 & 0.00125 & 3.5 & 350 & 0.00875 \\
\hline
\end{tabular}

第二表 對照試驗戀馝度

\begin{tabular}{|c|c|c|c|c|c|c|c|c|c|c|c|c|c|}
\hline \multirow{5}{*}{$\begin{array}{l}\text { 實 } \\
\text { 驗 } \\
\text { 番 } \\
\text { 號 }\end{array}$} & \multirow{5}{*}{$\begin{array}{l}\text { 生 } \\
\text { 存 } \\
\text { 匹 } \\
\text { 數 }\end{array}$} & \multicolumn{2}{|c|}{ 尾 } & \multicolumn{2}{|c|}{ 長 } & \multicolumn{2}{|c|}{ 後 } & \multicolumn{2}{|c|}{ 肢 } & \multicolumn{2}{|c|}{ 前 } & \multicolumn{2}{|l|}{ 肢 } \\
\hline & & $\equiv$ & 四 & 八 & + & 注 & 四 & $\equiv$ & $=$ & 兩 & 卓 & 前 & 雨 \\
\hline & & 粍 & 1 & 1 & $\dot{\overline{\mid}}$ & 粍 & 粍 & 粍 & 粍 & 側 & 側 & 肢 & 側 \\
\hline & & 以 & 七 & \pm & $\begin{array}{l}\text { 愁 } \\
\text { 以 }\end{array}$ & 以 & 程 & 程 & 以 & 發 & 發 & 箬 & 㫤 \\
\hline & & 下 & 秏 & 粍 & 正 & 上 & 度 & 度 & 下 & 生 & 生 & 明 & 生 \\
\hline (0) $\mathrm{K}$ & 10 & & & & 10 & & & 2 & 8 & & & & 10 \\
\hline
\end{tabular}

$\underset{\text { 分 }}{\text { 九 }}$

第三表 對照 試 驗 結 果（數值八平均值、單位八粍）

\begin{tabular}{|c|c|c|c|c|c|c|c|}
\hline 實驗番號 & 區分 & 全 長 & 尾 長 & 胴 圍 & 後 肢 & 前 肢 & 戀態數 \\
\hline \multirow{3}{*}{ (0) K } & 始 & 24.1 & 14.9 & 17.4 & 0 & 0 & \\
\hline & 終 & 23.3 & 14.5 & 16.2 & 1.5 & 0 & $\frac{0}{10}$ \\
\hline & 差 & -0.8 & -0.4 & -1.2 & & & \\
\hline
\end{tabular}




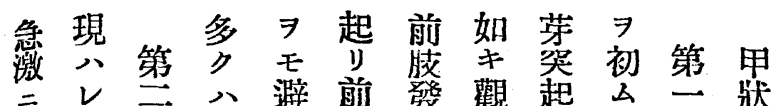

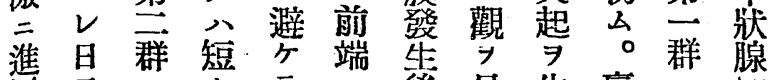
展 $\Rightarrow=\eta テ=$ 後呈生赢 $=$ 䍡 追於且静 八尾不ズ政於酸

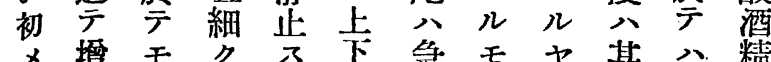
メ 增 モ

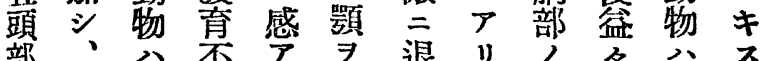

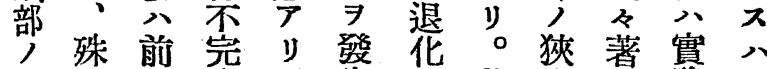

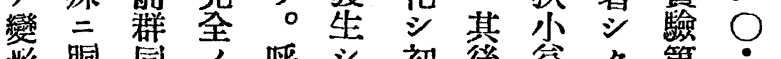

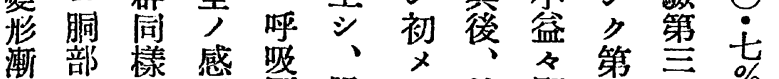
次人, 强整眼、前顯六百浮 登贏變》、難球最脽著草頃游

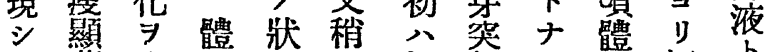

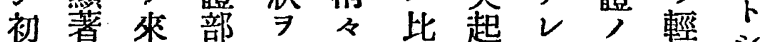

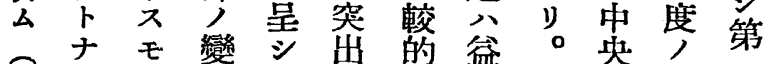
第り、態死淮其冬此部䇔群

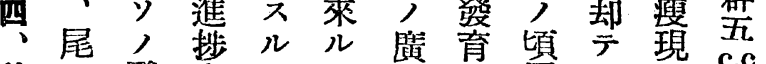
第 $モ$ 發 亦 モ モ サ シ 尾狹 V

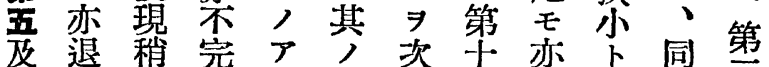

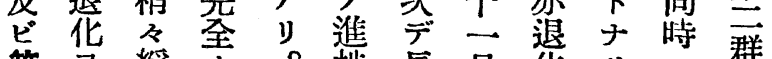

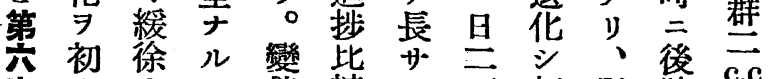

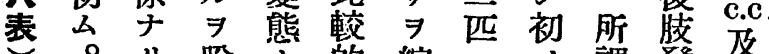

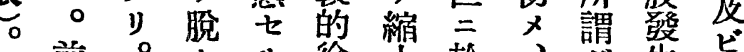
前即で動徐少於或宁牲第

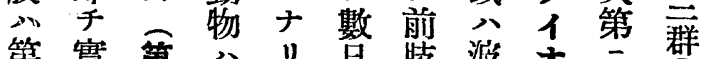

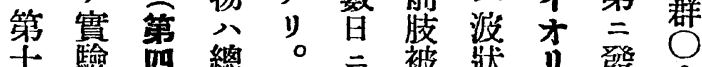

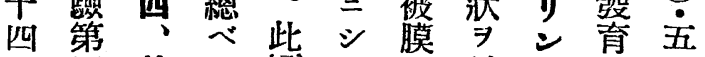

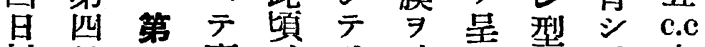

以日五赢、㱠破不寻、宛

來後度溲動第 り 七肢 ビ强物大テモ至六 四發楞分部發, 白間

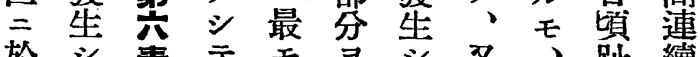

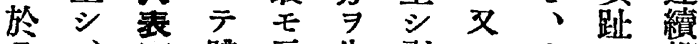

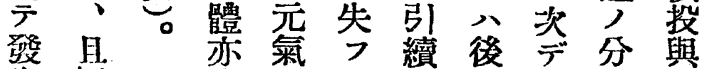
生輕尔不。篮體化セ

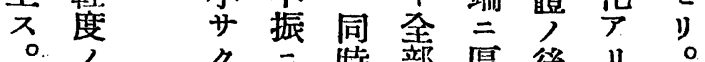

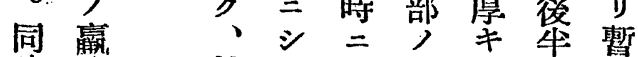
時瘦 前 $テ$ 頭前部益 方

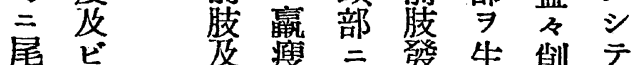
, 元 ビ强モ生莎關

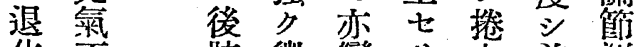

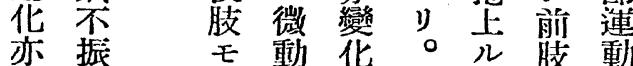

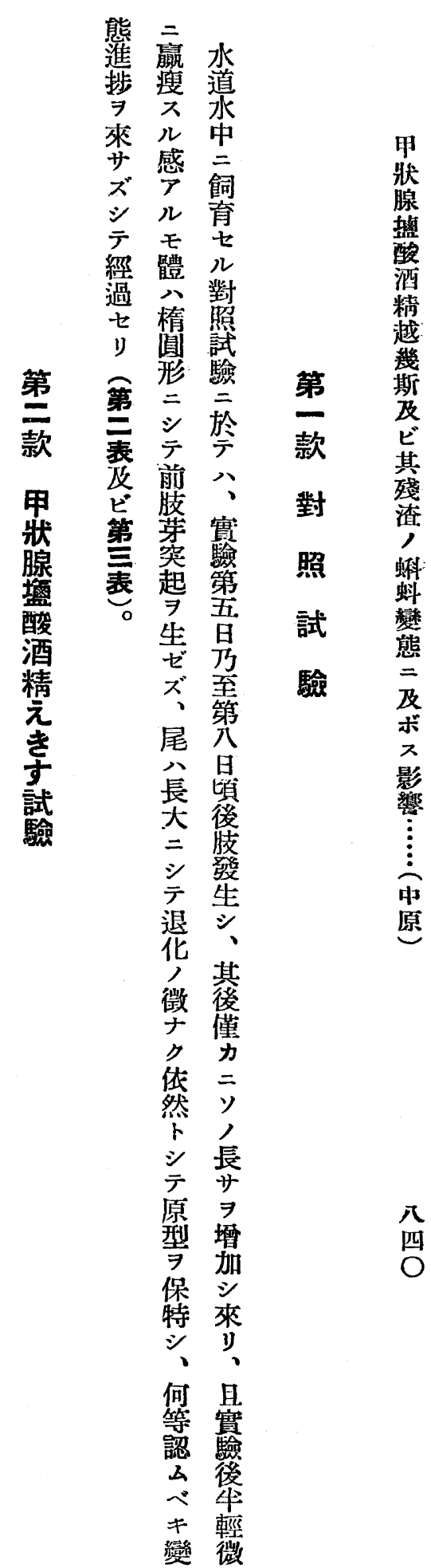




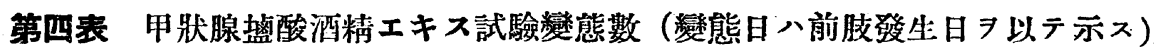

\begin{tabular}{|c|c|c|c|c|c|c|c|c|c|c|c|c|c|}
\hline $\begin{array}{l}\text { 實 } \\
\text { 驗 } \\
\text { 番 } \\
\text { 號 }\end{array}$ & $\begin{array}{l}\text { 生 } \\
\text { 存 } \\
\mathrm{v} \\
\text { 數 }\end{array}$ & $\begin{array}{l}\text { 第 } \\
\text { 十 } \\
\text { 日 }\end{array}$ & $\frac{\text { 第 }}{+}$ & $\begin{array}{l}\text { 第 } \\
+\frac{1}{日} \\
\frac{\vec{\theta}}{二}\end{array}$ & $\begin{array}{l}\text { 第 } \\
\stackrel{+}{\text { 至 }} \\
\text { 日 }\end{array}$ & $\begin{array}{l}\text { 第 } \\
+ \\
\text { 四 } \\
\text { 日 }\end{array}$ & $\begin{array}{l}\text { 第 } \\
\text { 十 } \\
\text { 吾 } \\
\text { 日 }\end{array}$ & $\begin{array}{l}\text { 第 } \\
+\frac{1}{\text { 日 }} \\
\text { 音 }\end{array}$ & $\begin{array}{l}\text { 第 } \\
\text { 上 } \\
\text { 七 } \\
\text { 日 }\end{array}$ & $\begin{array}{l}\text { 第 } \\
\text { 上 } \\
\text { 公 } \\
\text { 日 }\end{array}$ & $\begin{array}{l}\text { 第 } \\
\text { 十 } \\
\text { 杂 } \\
\text { 日 }\end{array}$ & $\frac{\text { 第 }}{\stackrel{二}{二}}$ & $\begin{array}{l}\text { 彎 } \\
\text { 態 } \\
\text { 点 } \\
\text { 數 }\end{array}$ \\
\hline (1) EX & $9(7)^{*}$ & & 2 & 1. & 1 & 2 & 2 & & 1 & & & & $9(7)$ \\
\hline (2) Ex & 9 & & & & & 1 & 1 & 2 & 1 & 1 & 1 & & 7 \\
\hline (3) eX & 9 & & & & & & 2 & 1 & & 1 & 1 & & 5 \\
\hline
\end{tabular}

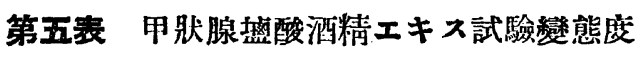

\begin{tabular}{|c|c|c|c|c|c|c|c|c|c|c|c|c|c|}
\hline 實 & \multirow{2}{*}{$\begin{array}{l}\text { 生 } \\
\text { 存 }\end{array}$} & \multicolumn{2}{|c|}{ 尾 } & \multicolumn{2}{|c|}{ 長 } & \multicolumn{2}{|c|}{ 後 } & \multicolumn{2}{|c|}{ 肢 } & \multicolumn{2}{|c|}{ 前 } & \multicolumn{2}{|c|}{ 肢 } \\
\hline 騟 & & $\equiv$ & 四 & 八 & + & 五 & 四 & $\equiv$ & $=$ & 兩 & H & 前 & 丽 \\
\hline 番 & $\mathrm{pc}$ & 粙 & 1 & 士 & $\overline{\bar{F}}$ & 粍 & 饿 & 粍 & 粍 & 側 & 㒋 & 䁌 & 側 \\
\hline & & 以 & 七 & I & 以 & 以 & 程 & 程 & 以 & 發 & 發 & 著 & 炎 \\
\hline 虩 & 數 & 下 & 粍 & 粍 & 上 & 上 & 度 & 度 & 下 & 生 & 生 & 明 & 生 \\
\hline (1) $\mathrm{EX}$ & 7 & 5 & 2 & & & 6 & 1 & & & 6 & 1 & & 0 \\
\hline (2) $\mathrm{Ex}$ & 9 & 2 & 2 & 4 & 1 & 7 & 1 & 1 & & 4 & $\mathbf{3}$ & & 2 \\
\hline (3) eX & 9 & & 3 & 4 & 2 & 5 & 2 & 2 & & 4 & 1 & & 4 \\
\hline
\end{tabular}

原

第六表 甲狀腺临酸酒精エキス試驗結果

\begin{tabular}{|c|c|c|c|c|c|c|c|}
\hline 實驗番號 & 區分 & 全 長 & 尾 長 & 胴 圍 & 後 肢 & 前 肢 & 變態數 \\
\hline (1) $\mathrm{EX}$ & $\begin{array}{l}\text { 始 } \\
\text { 終 } \\
\text { 差 }\end{array}$ & $\begin{array}{r}24.2 \\
9.6 \\
-14.6\end{array}$ & $\begin{array}{r}14.8 \\
2.5 \\
-12.3\end{array}$ & $\begin{array}{r}18.0 \\
6.4 \\
-11.6\end{array}$ & $\begin{array}{l}0 \\
5.1\end{array}$ & $\begin{array}{l}0 \\
2.9\end{array}$ & $\frac{9}{9}\left(\frac{7}{7}\right)$ \\
\hline (2) Ex & $\begin{array}{l}\text { 始 } \\
\text { 終 } \\
\text { 差 }\end{array}$ & $\begin{array}{r}24.0 \\
14.2 \\
-9.8\end{array}$ & $\begin{array}{r}14.8 \\
7.7 \\
-\quad 7.1\end{array}$ & $\begin{array}{r}17.2 \\
7.8 \\
-\quad 9.4\end{array}$ & $\begin{array}{l}0 \\
5.0\end{array}$ & $\begin{array}{l}0 \\
2.0\end{array}$ & $\frac{7}{9}$ \\
\hline (3) eX & $\begin{array}{l}\text { 始 } \\
\text { 終 } \\
\text { 差 }\end{array}$ & $\begin{array}{r}23.8 \\
16.2 \\
-\quad 7.4\end{array}$ & $\begin{array}{r}14.4 \\
8.6 \\
-\quad 5.8\end{array}$ & $\begin{array}{r}17.6 \\
10.0 \\
-\quad 7.6\end{array}$ & $\begin{array}{l}0 \\
4.8\end{array}$ & $\begin{array}{l}0 \\
1.5\end{array}$ & $\frac{5}{9}$ \\
\hline
\end{tabular}


第芯 、当胀 基體 第甲

五第 突尾资後漸 留

群出, 第盆次群腺

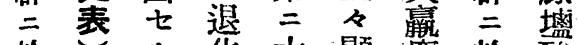

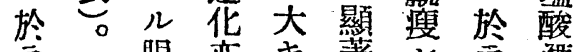

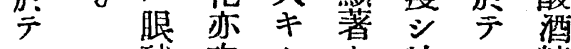

士 球次 ク

前 第ナナ二動 戏

群 鹰著

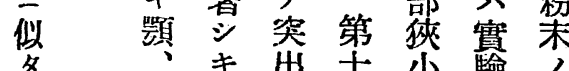

儿 叮 7 出古尔簽十

變 凸 加眼百第古

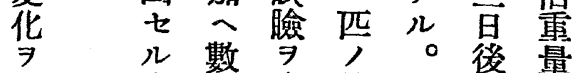

來皮怒生前尾肢量

ス膚二㛈モ發理

七 $\quad \exists$ 前 被帟生食

有

严過 $=$ 力第水

發、坐公破立五

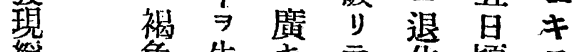

䜌色失 $\neq$ 华頃

徐斑 フ上發 7 趾

點。卡留初分第

シ $\Rightarrow$ 變, 勏分四

テ、有熊顎引 ル化群

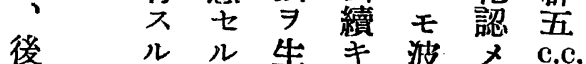

肢炭動总全 獎 ラ

菑公颔部、是、第

驗 變 前面前第群

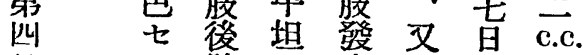

昆彩共生公䝨及

發人三リ、上第

生 ア $コ 、 0$ 運六

シ 。登皮前如動 群

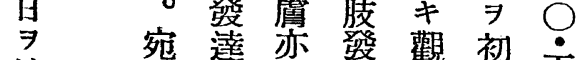

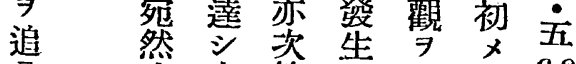

發 少成第占呈 星

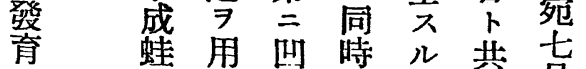

シ $\quad \exists$ 凸

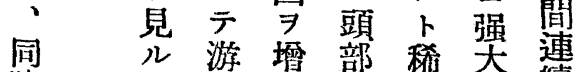

特 如泳加 哭企續

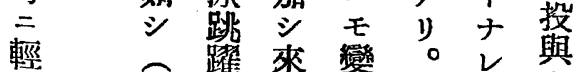

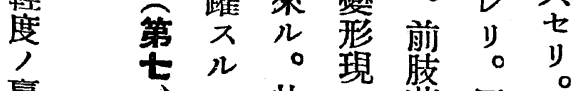

贏吉此少繁同。

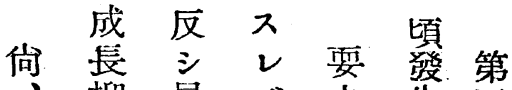

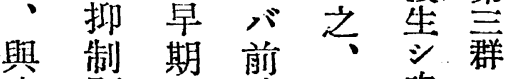

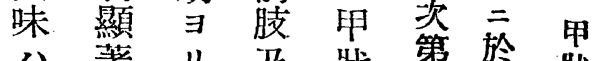

八著り及狀第於喿

若 二 全ビ腺發八腺

ク發身後 盐登動 酸

以現人肢酸辛物酒

上ル 湾 發精 長第精

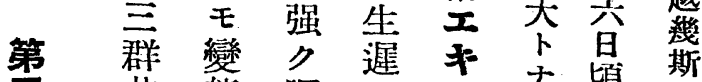

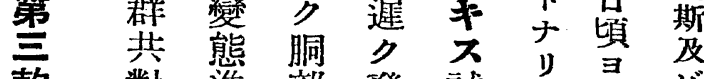

對進部發試、䛌

照涉ノ育 驗 前 輕 其

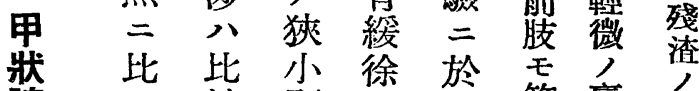

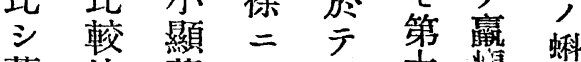

著的著 シ八士业 蝌

酸 著的者 シ 不

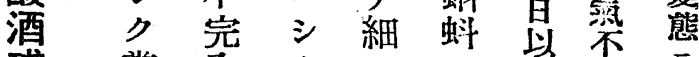

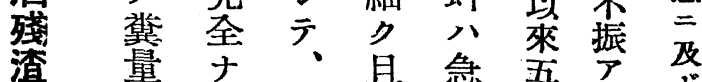

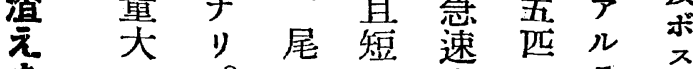

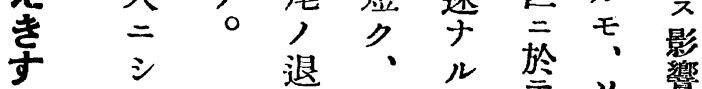

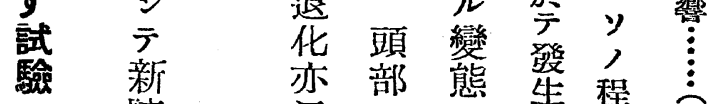

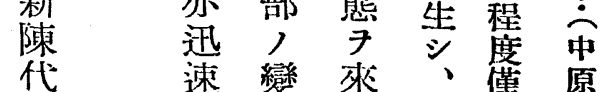

謝 二態 七 頭微 原

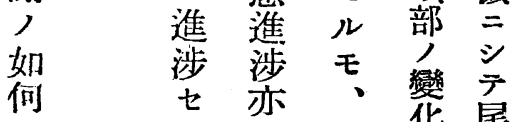

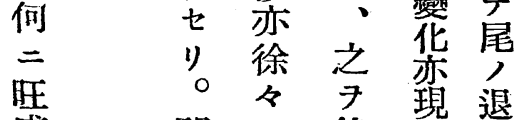

盛

カ

尹

窥睍

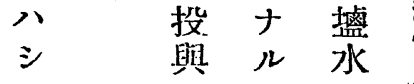

ム $=$ エ 第一

ル 依 脫手章点

ト

ナ

リ

リ七 ス 录

示試脽

蚪。驗第

蚪之侌菌 
第七表 甲狀腺盛酸酒精殘渣エキス試驗戀態數

\begin{tabular}{|c|c|c|c|c|c|c|c|c|c|c|c|c|c|}
\hline $\begin{array}{l}\text { 實 } \\
\text { 驗 } \\
\text { 番 } \\
\text { 號 }\end{array}$ & $\begin{array}{l}\text { 生 } \\
\text { 存 } \\
\text { 日 } \\
\text { 數 }\end{array}$ & $\begin{array}{l}\text { 第 } \\
\text { 十 } \\
\text { 日 }\end{array}$ & $\begin{array}{l}\text { 第 } \\
\stackrel{-1}{日} \\
\text { 日 }\end{array}$ & $\begin{array}{l}\text { 第 } \\
\stackrel{+上}{\frac{1}{二}}\end{array}$ & $\begin{array}{l}\text { 第 } \\
+\frac{1}{ \pm} \\
\text { 香 }\end{array}$ & $\begin{array}{l}\text { 第 } \\
+1 \\
\text { 回 } \\
\text { 日 }\end{array}$ & $\begin{array}{l}\text { 第 } \\
+1 \\
\text { 吾 } \\
\text { 日 }\end{array}$ & $\begin{array}{l}\text { 第 } \\
+\frac{1}{+} \\
\text { 六 } \\
\text { 日 }\end{array}$ & $\begin{array}{l}\text { 第 } \\
+ \\
\text { 志 } \\
\text { 日 }\end{array}$ & $\begin{array}{l}\text { 第 } \\
+ \\
\text { 公 } \\
\text { 日 }\end{array}$ & $\begin{array}{l}\text { 第 } \\
+ \\
\text { 杂 } \\
\text { 日 }\end{array}$ & $\begin{array}{l}\text { 第 } \\
= \\
\text { 直 }\end{array}$ & $\begin{array}{l}\text { 戀 } \\
\text { 態 } \\
\text { 范 } \\
\text { 數 }\end{array}$ \\
\hline (4) RS & 9 & 1 & 1 & 2 & & 2 & 2 & & 1 & & & & 9 \\
\hline (5) Rs & 9 & & & & & 2 & 1 & 1 & & 2 & & 1 & 7 \\
\hline (6) $\mathrm{rS}$ & 10 & & & & & & & 2 & & 1. & 1 & & 4 \\
\hline
\end{tabular}

第八表 甲狀腺漗酸酒精エキス試驗變態度

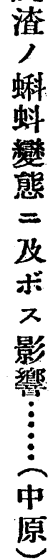

第九表 甲狀腺鎜酸酒精殘渣エキス試驗結果

\begin{tabular}{|c|c|c|c|c|c|c|c|}
\hline |實驗番號 & 區分 & 全 長 & 尾 長 & 胴 圈 & 後 䁌 & 前 肢 & 戀態數 \\
\hline (4) $\mathrm{RS}$ & $\begin{array}{l}\text { 始 } \\
\text { 終 } \\
\text { 羛 }\end{array}$ & $\begin{array}{r}23.6 \\
14.7 \\
-8.9\end{array}$ & $\begin{array}{r}14.7 \\
8.5 \\
-6.2\end{array}$ & $\begin{array}{r}17.3 \\
8.6 \\
-8.7\end{array}$ & $\begin{array}{l}0 \\
5.9\end{array}$ & $\begin{array}{l}0 \\
3.5\end{array}$ & $\frac{9}{9}$ \\
\hline (5) $\mathrm{Rs}$ & $\begin{array}{l}\text { 始 } \\
\text { 終 } \\
\text { 差 }\end{array}$ & $\begin{array}{r}23.3 \\
16.9 \\
-6.6\end{array}$ & $\begin{array}{r}14.2 \\
9.1 \\
-\quad 5.1\end{array}$ & $\begin{array}{r}17.4 \\
9.8 \\
-\quad 7.6\end{array}$ & $\begin{array}{l}0 \\
5.5\end{array}$ & $\begin{array}{l}0 \\
2.8\end{array}$ & $\frac{7}{9}$ \\
\hline (6) $\mathrm{rS}$ & $\begin{array}{l}\text { 始 } \\
\text { 終 } \\
\text { 差 }\end{array}$ & $\begin{array}{r}22.6 \\
17.7 \\
-4.9\end{array}$ & $\begin{array}{r}13.0 \\
9.6 \\
-\quad 3.4\end{array}$ & $\begin{array}{r}17.0 \\
10.2 \\
-\quad 6.8\end{array}$ & $\begin{array}{l}0 \\
5.0\end{array}$ & $\begin{array}{l}0 \\
1.4\end{array}$ & $\frac{4}{10}$ \\
\hline
\end{tabular}




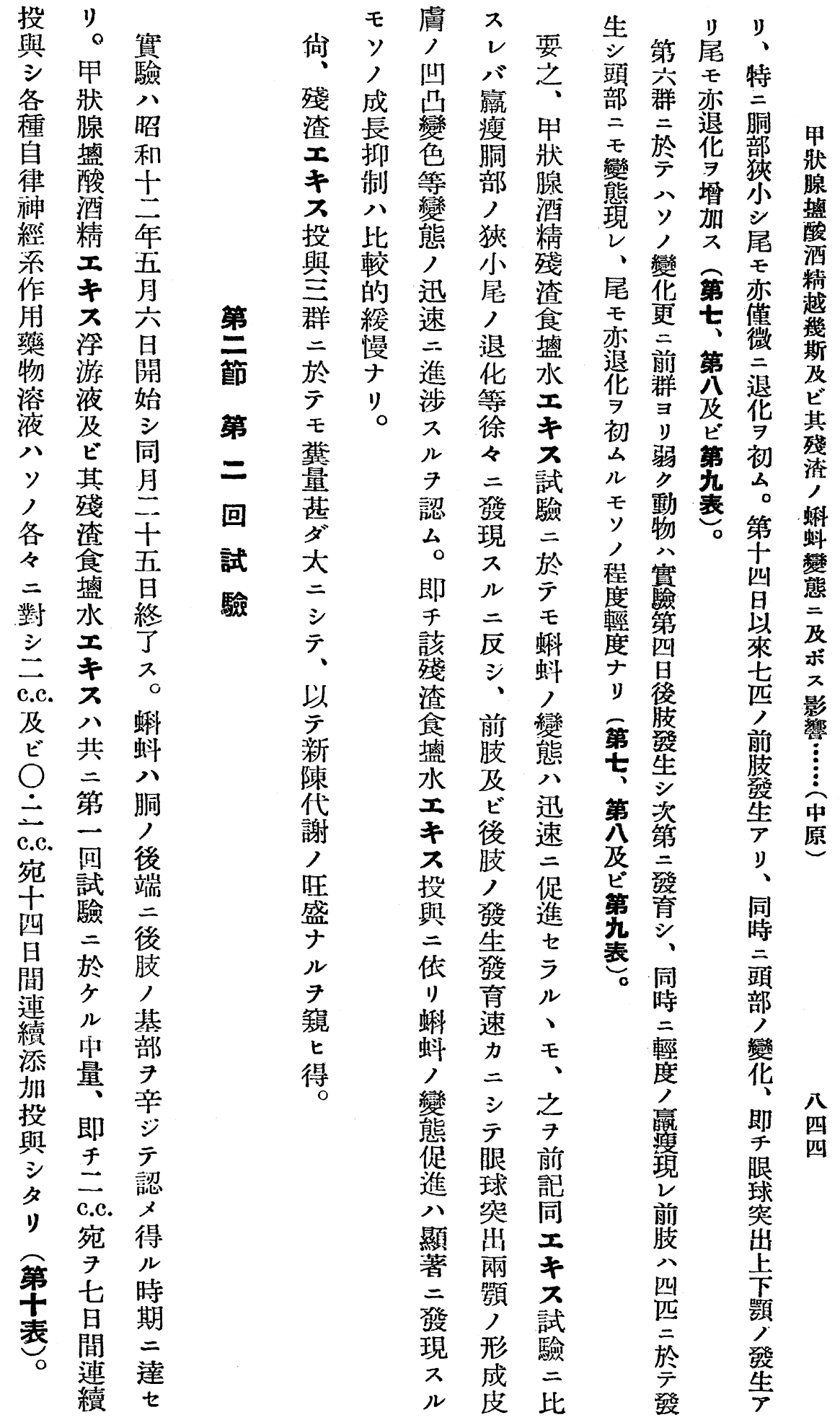




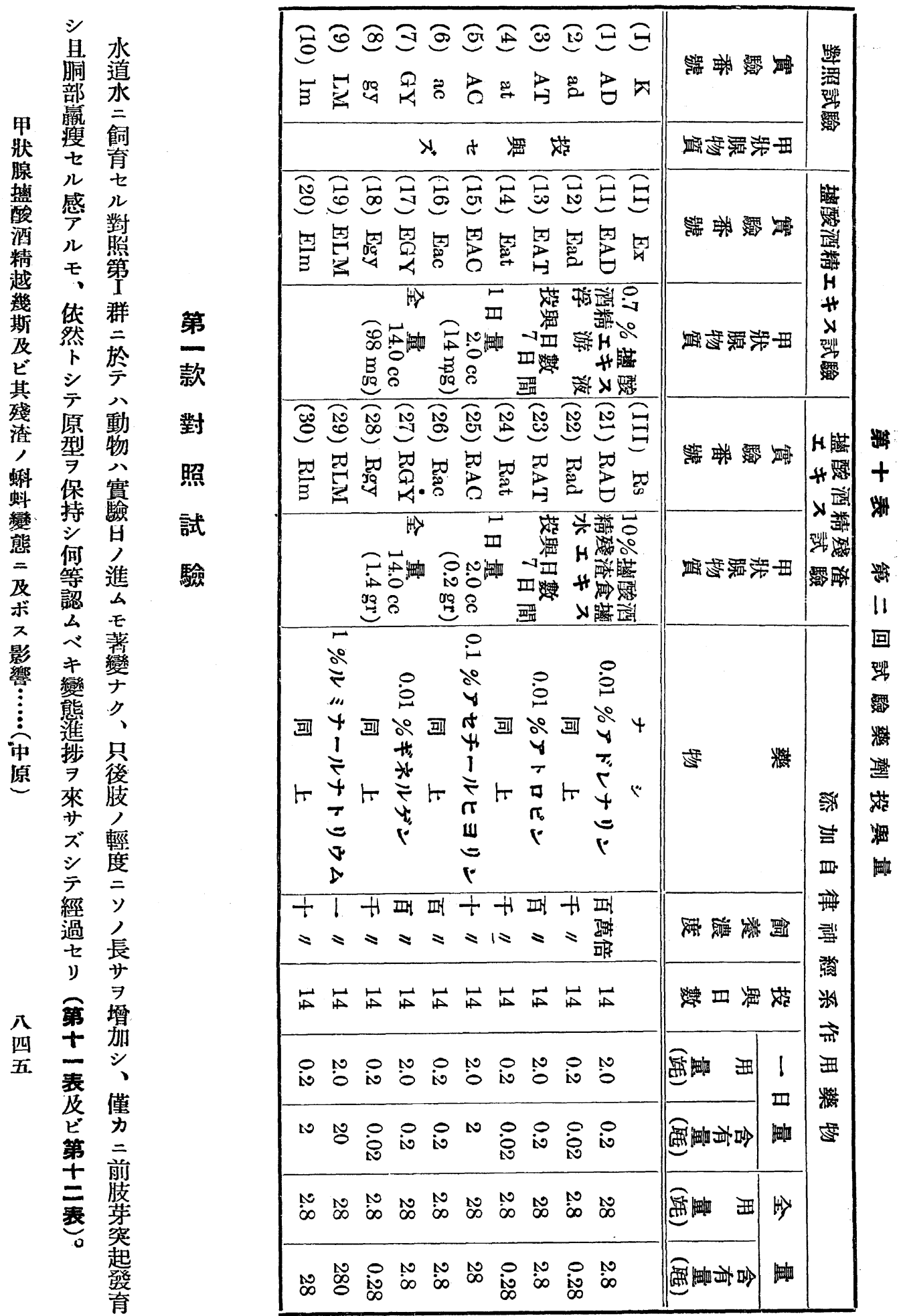


第十一表 對照試 驗變態度

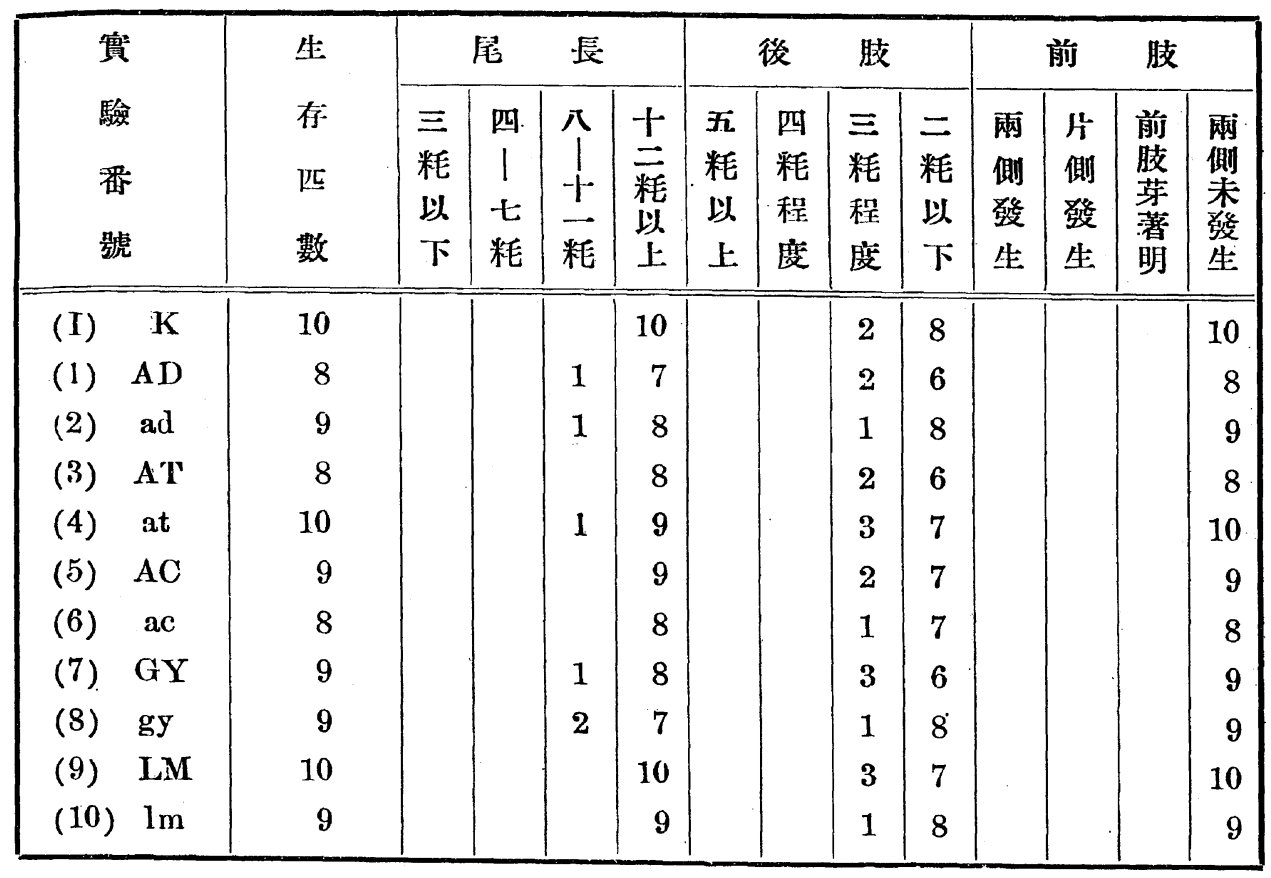

苐十二表 對 照 試 驗 結 果

\begin{tabular}{|c|c|c|c|c|c|c|c|}
\hline |實驗番號 & 區分 & 圣 長 & 尾 長 & 胴 圍 & 後 肢 & 前 肢 & 變態數 \\
\hline (I) $\mathrm{K}$ & $\begin{array}{l}\text { 始 } \\
\text { 終 } \\
\text { 差 }\end{array}$ & $\begin{array}{r}25.0 \\
24.1 \\
-\quad 0.9\end{array}$ & $\begin{array}{r}15.7 \\
15.0 \\
-\quad 0.7\end{array}$ & $\begin{array}{r}19.0 \\
16.5 \\
-\quad 2.5\end{array}$ & $\begin{array}{l}0 \\
1.9\end{array}$ & $\begin{array}{l}0 \\
0\end{array}$ & 0 \\
\hline (1) AD & $\begin{array}{l}\text { 始 } \\
\text { 終 } \\
\text { 差 }\end{array}$ & $\begin{array}{r}24.6 \\
23.4 \\
-\quad 1.2 \\
\end{array}$ & $\begin{array}{r}15.8 \\
14.8 \\
-\quad 1.0\end{array}$ & $\begin{array}{r}18.0 \\
16.5 \\
-\quad 1.5\end{array}$ & $\begin{array}{l}0 \\
2.1\end{array}$ & $\begin{array}{l}0 \\
0\end{array}$ & 0 \\
\hline (2) ad & $\begin{array}{l}\text { 始 } \\
\text { 終 } \\
\text { 差 }\end{array}$ & $\begin{array}{r}24.3 \\
23.5 \\
-\quad 0.8 \\
\end{array}$ & $\begin{array}{r}15.3 \\
14.2 \\
-\quad 1.1\end{array}$ & $\begin{array}{r}18.7 \\
16.2 \\
-\quad 2.5\end{array}$ & $\begin{array}{l}0 \\
1.8\end{array}$ & $\begin{array}{l}0 \\
0\end{array}$ & 0 \\
\hline (3) A'T & $\begin{array}{l}\text { 始 } \\
\text { 終 } \\
\text { 差 }\end{array}$ & $\begin{array}{r}24.2 \\
22.8 \\
-\quad 1.4 \\
\end{array}$ & $\begin{array}{r}15.0 \\
14.1 \\
-\quad 0.9 \\
\end{array}$ & $\begin{array}{r}18.6 \\
16.0 \\
-\quad 2.6 \\
\end{array}$ & $\begin{array}{l}0 \\
2.2\end{array}$ & $\begin{array}{l}0 \\
0\end{array}$ & 0 \\
\hline$(4)$ at & $\begin{array}{l}\text { 始 } \\
\text { 終 } \\
\text { 琴 }\end{array}$ & $\begin{array}{r}24.6 \\
23.2 \\
-\quad 1.4 \\
\end{array}$ & $\begin{array}{r}15.5 \\
14.2 \\
-1.3 \\
\end{array}$ & $\begin{array}{r}18.0 \\
15.7 \\
-\quad 2.3\end{array}$ & $\begin{array}{l}0 \\
2.2\end{array}$ & $\begin{array}{l}0 \\
0\end{array}$ & 0 \\
\hline
\end{tabular}




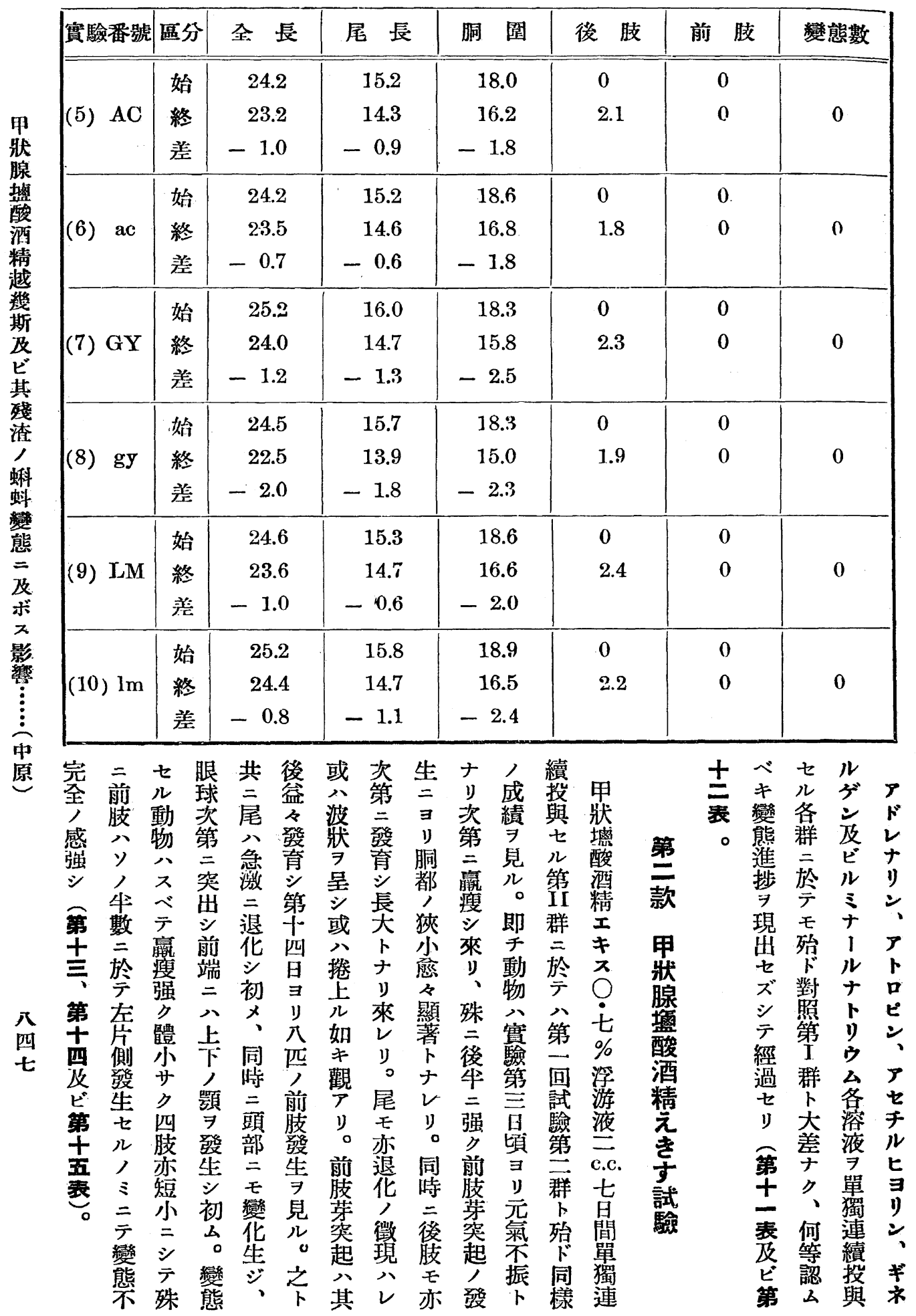


第十三表 甲踈腺撚酸酒精エキス試驗戀態數

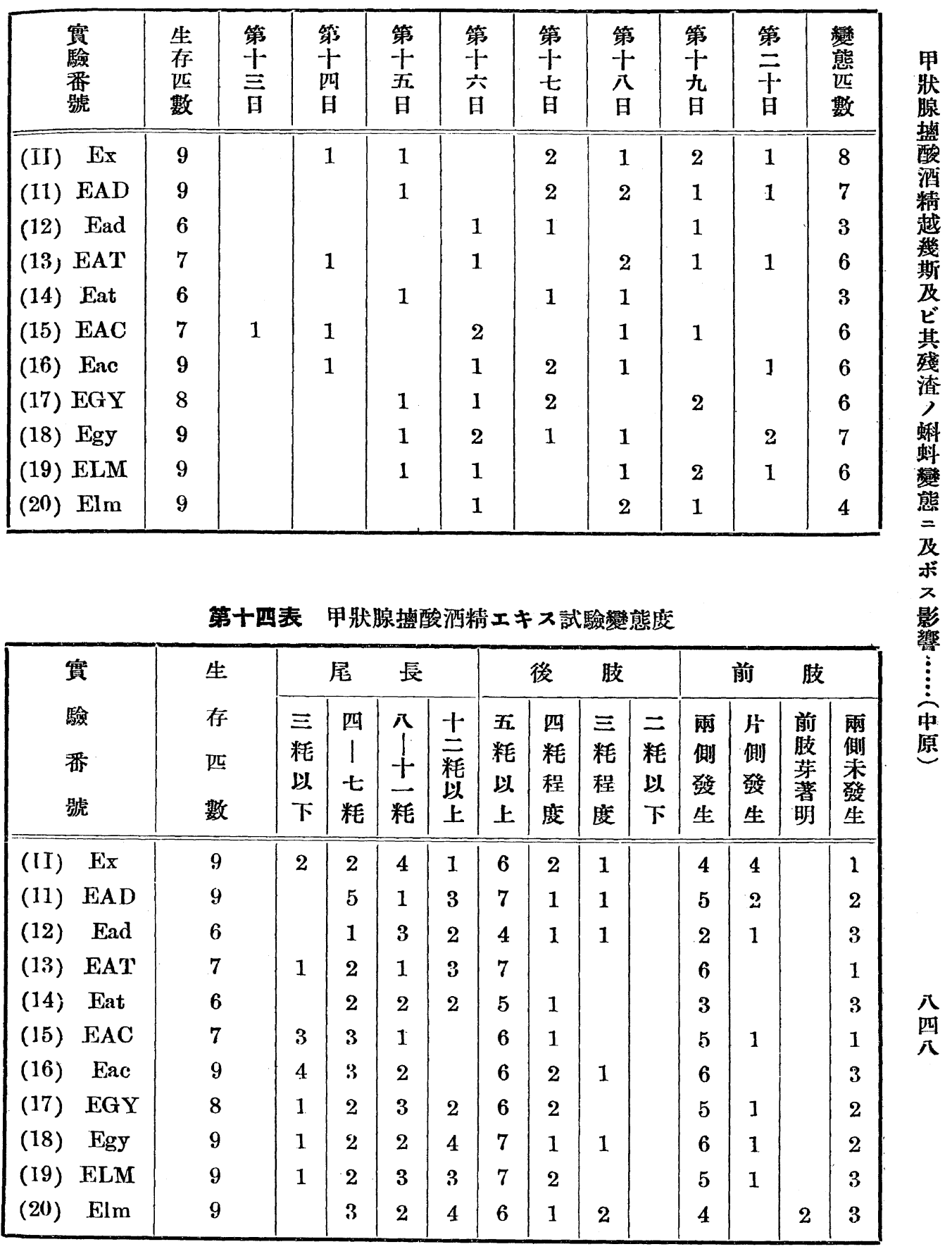


第十五表 甲狀腺盛酸酒精エキス試驗結果

\begin{tabular}{|c|c|c|c|c|c|c|c|}
\hline 實驗番號 & 區分 & 全 長 & 尾 長 & 胴 圍 & 後 肢 & 前 戝 & 變態數 \\
\hline (II) $\operatorname{Ex}$ & $\begin{array}{l}\text { 始 } \\
\text { 終 } \\
\text { 差 }\end{array}$ & $\begin{array}{r}25.2 \\
13.7 \\
-11.5\end{array}$ & $\begin{array}{r}16.0 \\
6.6 \\
-9.4\end{array}$ & $\begin{array}{r}18.0 \\
7.6 \\
-10.4 \\
\end{array}$ & $\begin{array}{l}0 \\
5.0\end{array}$ & $\begin{array}{l}0 \\
2.0\end{array}$ & $\frac{8}{9}$ \\
\hline (11) EAD & $\begin{array}{l}\text { 始 } \\
\text { 終 } \\
\text { 差 }\end{array}$ & $\begin{array}{r}34.0 \\
16.3 \\
-\quad 7.7\end{array}$ & $\begin{array}{r}14.8 \\
8.6 \\
-6.2 \\
\end{array}$ & $\begin{array}{r}18.6 \\
9.0 \\
-9.6 \\
\end{array}$ & $\begin{array}{l}0 \\
5.2\end{array}$ & $\begin{array}{l}0 \\
2.0\end{array}$ & $\frac{7}{9}$ \\
\hline (12) Ead & $\begin{array}{l}\text { 始 } \\
\text { 終 } \\
\text { 差 }\end{array}$ & $\begin{array}{r}24.8 \\
17.2 \\
-6.0\end{array}$ & $\begin{array}{r}15.6 \\
9.6 \\
-6.0\end{array}$ & $\begin{array}{r}18.6 \\
9.3 \\
-\quad 9.3\end{array}$ & $\begin{array}{l}0 \\
4.9\end{array}$ & $\begin{array}{l}0 \\
1.2\end{array}$ & $\frac{3}{6}$ \\
\hline (13) EAT & $\begin{array}{l}\text { 始 } \\
\text { 終 } \\
\text { 差 }\end{array}$ & $\begin{array}{r}24.5 \\
15.1 \\
-\quad 9.4\end{array}$ & $\begin{array}{r}15.6 \\
6.9 \\
-8.7\end{array}$ & $\begin{array}{r}18.2 \\
9.5 \\
-\quad 8.7\end{array}$ & $\begin{array}{l}0 \\
5.5\end{array}$ & $\begin{array}{l}0 \\
2.6\end{array}$ & $\frac{6}{7}$ \\
\hline (14) Eat & $\begin{array}{l}\text { 始 } \\
\text { 終 } \\
\text { 差 }\end{array}$ & $\begin{array}{r}24.0 \\
16.0 \\
-\quad 8.0 \\
\end{array}$ & $\begin{array}{r}14.9 \\
8.7 \\
-\quad 6.2 \\
\end{array}$ & $\begin{array}{r}18.3 \\
10.0 \\
-\quad 8.3 \\
\end{array}$ & $\begin{array}{l}0 \\
5.0\end{array}$ & $\begin{array}{l}0 \\
1.5\end{array}$ & -3 \\
\hline (15) EAC & $\begin{array}{l}\text { 始 } \\
\text { 終 } \\
\text { 洼 }\end{array}$ & $\begin{array}{r}25.1 \\
12.5 \\
-12.6\end{array}$ & $\begin{array}{r}15.9 \\
4.7 \\
-11.2\end{array}$ & $\begin{array}{r}18.9 \\
6.7 \\
-12.2\end{array}$ & $\begin{array}{l}0 \\
5.2\end{array}$ & $\begin{array}{l}0 \\
2.1\end{array}$ & $\frac{6}{7}$ \\
\hline (16) Eac & $\begin{array}{l}\text { 始 } \\
\text { 終 } \\
\text { 美 }\end{array}$ & $\begin{array}{r}24.8 \\
12.5 \\
-12.3\end{array}$ & $\begin{array}{r}15.6 \\
5.9 \\
-\quad 9.7\end{array}$ & $\begin{array}{r}18.6 \\
8.3 \\
-10.3\end{array}$ & $\begin{array}{l}0 \\
4.8\end{array}$ & $\begin{array}{l}0 \\
2.0\end{array}$ & $\frac{6}{9}$ \\
\hline (17) EGY & $\begin{array}{l}\text { 始 } \\
\text { 終 } \\
\text { 美 }\end{array}$ & $\begin{array}{r}24.5 \\
15.6 \\
-8.9\end{array}$ & $\begin{array}{r}15.3 \\
8.6 \\
-6.7\end{array}$ & $\begin{array}{r}18.6 \\
8.6 \\
-10.0\end{array}$ & $\begin{array}{l}0 \\
5.1\end{array}$ & $\begin{array}{l}0 \\
2.0\end{array}$ & $\frac{6}{8}$ \\
\hline (18) Egy & $\begin{array}{l}\text { 始 } \\
\text { 終 } \\
\text { 差 }\end{array}$ & $\begin{array}{r}25.3 \\
16.2 \\
-\quad 9.1\end{array}$ & $\begin{array}{r}15.8 \\
8.8 \\
-\quad 7.0\end{array}$ & $\begin{array}{r}18.5 \\
8.7 \\
-9.8\end{array}$ & $\begin{array}{l}0 \\
5.2\end{array}$ & $\begin{array}{l}0 \\
2.2\end{array}$ & $\begin{array}{l}7 \\
9\end{array}$ \\
\hline (19) ELM & $\begin{array}{l}\text { 始 } \\
\text { 終 } \\
\text { 差 }\end{array}$ & $\begin{array}{r}25.3 \\
17.6 \\
-\quad 7.7\end{array}$ & $\begin{array}{r}15.1 \\
8.7 \\
-6.4\end{array}$ & $\begin{array}{r}18.5 \\
8.6 \\
-9.9\end{array}$ & $\begin{array}{l}0 \\
5.3\end{array}$ & $\begin{array}{l}0 \\
1.8\end{array}$ & $\frac{6}{9}$ \\
\hline (20) Elm & $\begin{array}{l}\text { 始 } \\
\text { 終 } \\
\text { 美 }\end{array}$ & $\begin{array}{r}25.2 \\
17.7 \\
-\quad 7.5\end{array}$ & $\begin{array}{r}16.0 \\
9.5 \\
-6.5\end{array}$ & $\begin{array}{r}18.5 \\
9.9 \\
-\quad 8.6\end{array}$ & $\begin{array}{l}0 \\
4.8\end{array}$ & $\begin{array}{l}0 \\
1.3\end{array}$ & $\frac{4}{9}$ \\
\hline
\end{tabular}




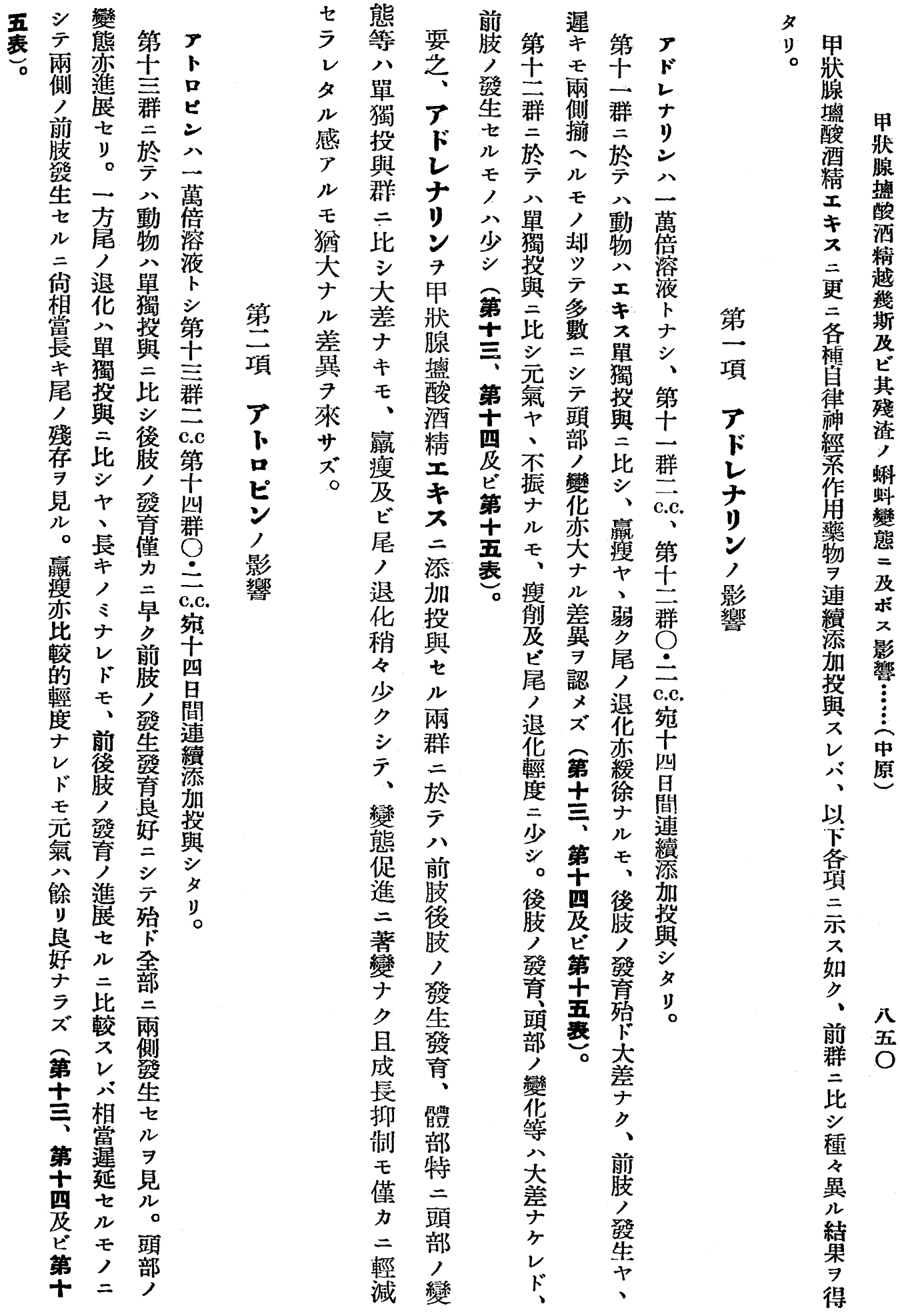




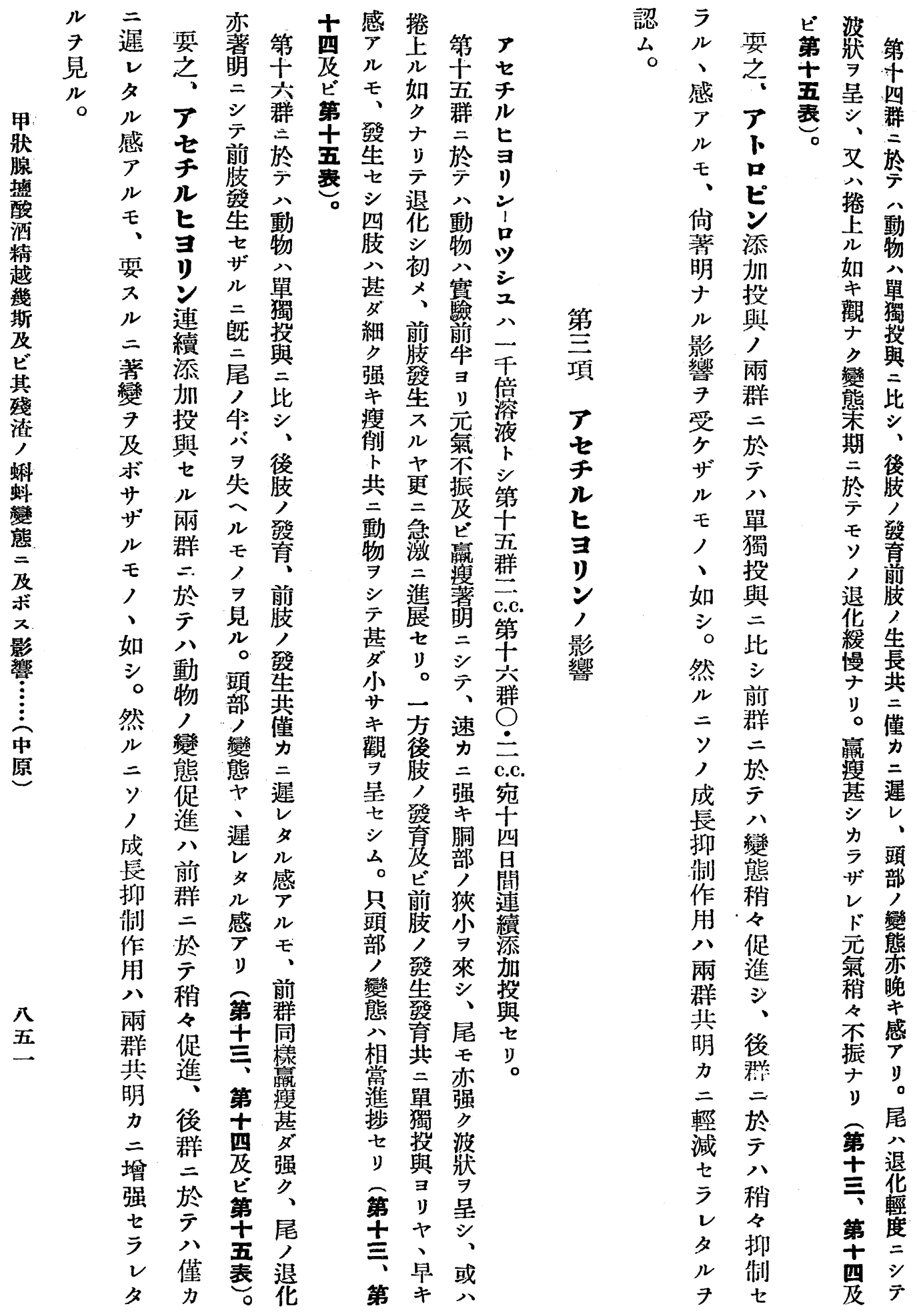




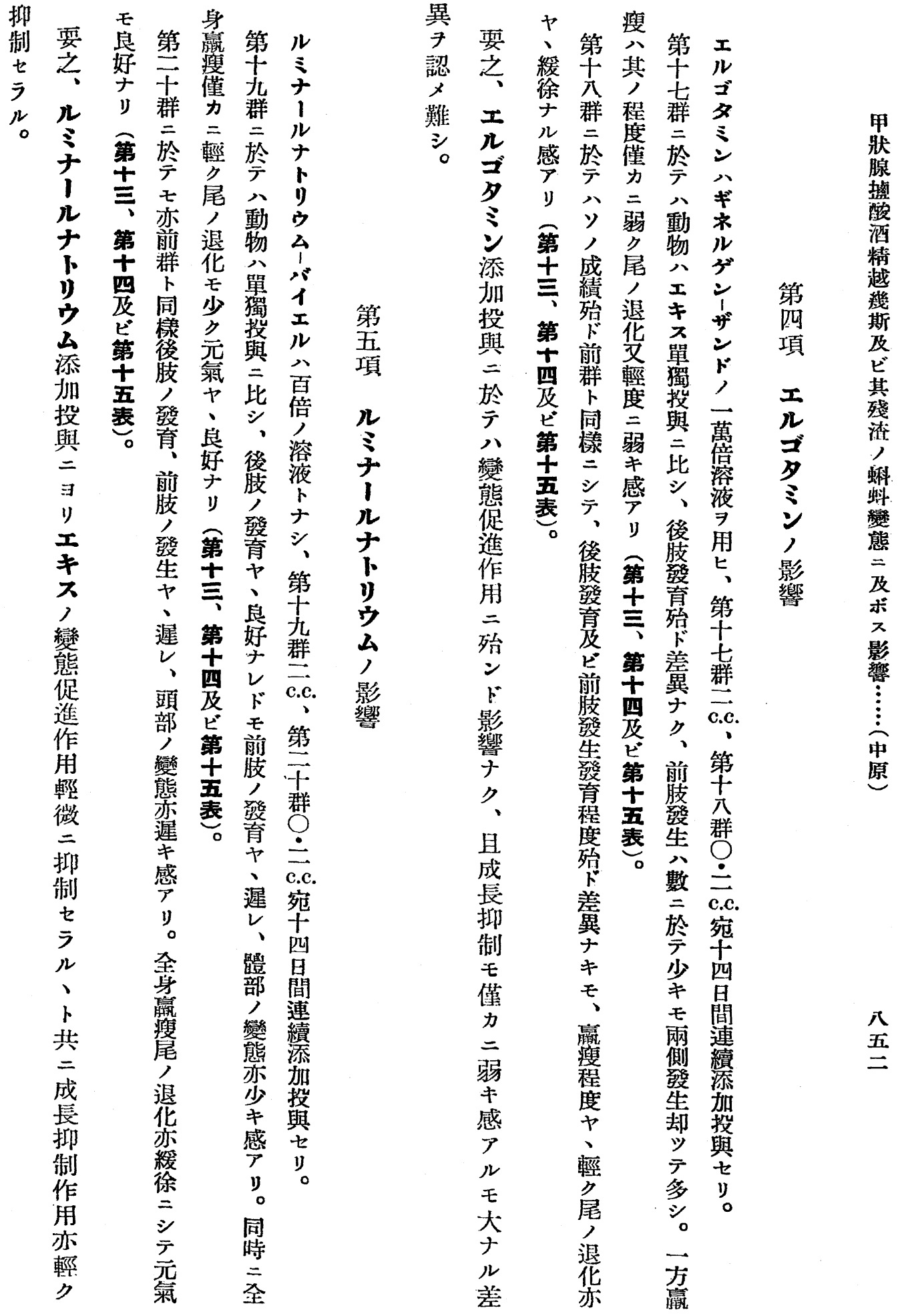



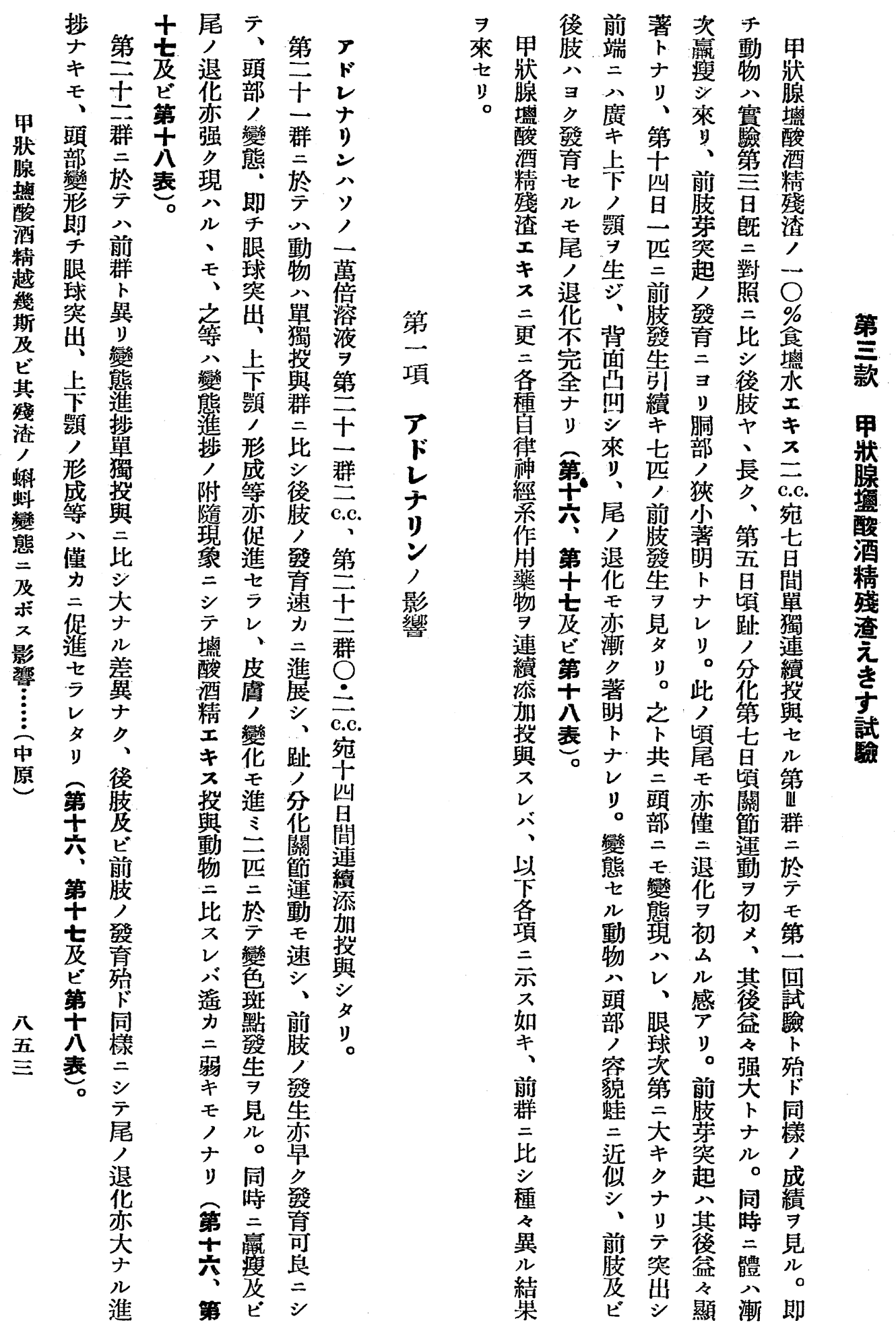
第十六表 甲狀腺壚酸酒精殘渣エキス試驗變龍數

\begin{tabular}{|c|c|c|c|c|c|c|c|c|c|c|}
\hline $\begin{array}{l}\text { 翼 } \\
\text { 驗 } \\
\text { 番 } \\
\text { 號 }\end{array}$ & $\begin{array}{l}\text { 生 } \\
\text { 存 } \\
\text { 菏 } \\
\text { 數 }\end{array}$ & $\begin{array}{l}\text { 第 } \\
+\frac{1}{日} \\
\text { 日 }\end{array}$ & $\begin{array}{l}\text { 第 } \\
+ \\
\text { 四 } \\
\text { 日 }\end{array}$ & $\begin{array}{l}\text { 第 } \\
\text { 十 } \\
\text { 吾 } \\
\text { 日 }\end{array}$ & $\begin{array}{l}\text { 第 } \\
+ \\
+\frac{1}{\text { 日 }} \\
\end{array}$ & $\begin{array}{l}\text { 第 } \\
+十 \\
\text { 匕 } \\
\text { 日 }\end{array}$ & $\begin{array}{l}\text { 第 } \\
+ \\
\text { 分 } \\
\text { 日 }\end{array}$ & $\begin{array}{l}\text { 第 } \\
\text { 十 } \\
\text { 艻 } \\
\text { 日 }\end{array}$ & $\frac{\text { 第 }}{\stackrel{\overrightarrow{1}}{二}}$ & $\begin{array}{l}\text { 彎 } \\
\text { 態 } \\
\text { 正 } \\
\text { 數 }\end{array}$ \\
\hline (III) Rs & 10 & & 1 & & 2 & 2 & 1 & 1 & & 7 \\
\hline (21) RAD & 9 & 1 & 2 & 2 & 1 & & 1 & 1 & & 8 \\
\hline (22) Rad & 9 & & & 1 & 1 & & 2 & 1. & & 5 \\
\hline (23) BAT & 9 & & & & 1 & & 2 & 1 & & 4 \\
\hline (24) Rat & 6 & & & 1 & & 1 & 1 & 1 & & 4 \\
\hline (25) RAC & 9 & & & & 1 & 1 & & & 1 & 3 \\
\hline (26) Rac & 6 & & & 1 & & 1 & & 2 & & 4 \\
\hline (27) RGY & 6 & & & & & & & & & 0 \\
\hline (28) Rgy & 8 & & & & & 1 & 2 & & 1 & 4 \\
\hline (29) RIM & 10 & & & & 1 & 2 & & 1 & 1 & 5 \\
\hline (30) Rlm & 10 & & & 1 & & 1 & 2 & & 1 & 5 \\
\hline
\end{tabular}

第十七表 甲狀腺㪇酸酒精殘渣エキス試驗變態度

\begin{tabular}{|c|c|c|c|c|c|c|c|c|c|c|c|c|c|}
\hline 實 & & & 尾 & 長 & & & 㘼 & 肢 & & & 䍩 & 肢 & \\
\hline $\begin{array}{l}\text { 驗 } \\
\text { 番 } \\
\text { 號 }\end{array}$ & $\begin{array}{l}\text { 存 } \\
\text { 匹 } \\
\text { 數 }\end{array}$ & $\begin{array}{l}\text { 三 } \\
\text { 秏 } \\
\text { 以 } \\
\text { 下 }\end{array}$ & $\begin{array}{c}\text { 四 } \\
1 \\
\text { 七 } \\
\text { 粕 }\end{array}$ & 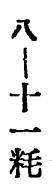 & $\begin{array}{l}\text { 上 } \\
\text { 粍 } \\
\text { 上 } \\
\text { 上 }\end{array}$ & $\begin{array}{l}\text { 五 } \\
\text { 粍 } \\
\text { 以 } \\
\text { 上 }\end{array}$ & $\begin{array}{l}\text { 四 } \\
\text { 粍 } \\
\text { 程 } \\
\text { 度 }\end{array}$ & $\begin{array}{l}\text { 三 } \\
\text { 粍 } \\
\text { 程 } \\
\text { 度 }\end{array}$ & $\begin{array}{l}\text { 二 } \\
\text { 粍 } \\
\text { 以 } \\
\text { 下 }\end{array}$ & $\begin{array}{l}\text { 兩 } \\
\text { 側 } \\
\text { 發 } \\
\text { 生 }\end{array}$ & $\begin{array}{l}f^{L} \\
\text { 側 } \\
\text { 發 } \\
\text { 生 }\end{array}$ & $\begin{array}{l}\text { 前 } \\
\text { 膵 } \\
\text { 芽 } \\
\text { 著 } \\
\text { 明 }\end{array}$ & $\begin{array}{l}\text { 网 } \\
\text { 侧 } \\
\text { 年 } \\
\text { 發 } \\
\text { 生 }\end{array}$ \\
\hline (III) Rs & 10 & 1 & 2 & 2 & 5 & 7 & 3 & & & 6 & 1 & & $\mathbf{3}$ \\
\hline (21) RAD & 9 & 3 & 2 & 2 & 2 & 9 & & & & 8 & & & 1 \\
\hline (22) $\operatorname{Rad}$ & 9 & 1 & 3 & 3 & 2 & 6 & 3 & & & 5 & & & 4 \\
\hline (23) $\mathrm{RA} T$ & 9 & & 2 & 4 & 3 & 6 & 2 & 1 & & 4 & & 1 & 4 \\
\hline (24) Rat & 6 & 1 & 2 & 1 & 2 & 4 & 2 & & & 4 & & & 2 \\
\hline (25) RAC & 9 & & & 3 & 6 & 6 & 2 & 1 & & 3 & & & 6 \\
\hline (26) Rac & 6 & & 2 & 2 & 2 & 5 & 1 & & & 3 & 1 & & 2 \\
\hline (27) RGY & 9 & & & 2 & 7 & 2 & 1 & 1 & 4 & & & 2 & 7 \\
\hline (28) Rgy & 8 & & & 3 & 5 & 6 & 1 & 2 & & 3 & & & 4 \\
\hline (29) RLM & 10 & & & 3 & 7 & 4 & 3 & 3 & & 5 & & & 5 \\
\hline (30) Rlm & 10 & & & 4 & 6 & 6 & 2 & 2 & & 4 & 1 & & 5 \\
\hline
\end{tabular}


第十八表 甲狀腺㙟酸酒精殘渣エキス試驗結果

\begin{tabular}{|c|c|c|c|c|c|c|c|}
\hline 實驗番號 & 區分 & 企 長 & 尾 長 & 胴 圍 & 後 肢 & 前 肢 & 變態數 \\
\hline (III) Rs & $\begin{array}{l}\text { 始 } \\
\text { 終 } \\
\text { 差 }\end{array}$ & $\begin{array}{r}24.8 \\
15.7 \\
-\quad 9.1\end{array}$ & $\begin{array}{r}15.6 \\
8.4 \\
-7.2\end{array}$ & $\begin{array}{r}18.6 \\
9.8 \\
-\quad 8.8\end{array}$ & $\begin{array}{l}0 \\
5.6\end{array}$ & $\begin{array}{l}0 \\
2.5\end{array}$ & $\frac{7}{10}$ \\
\hline (21) RAD & $\begin{array}{l}\text { 始 } \\
\text { 終 } \\
\text { 差 }\end{array}$ & $\begin{array}{r}25.0 \\
14.8 \\
-10.2\end{array}$ & $\begin{array}{r}15,7 \\
7.0 \\
-8.7\end{array}$ & $\begin{array}{r}18.9 \\
9.2 \\
-\quad 9.7\end{array}$ & $\begin{array}{l}0 \\
6.1\end{array}$ & $\begin{array}{l}0 \\
3.1\end{array}$ & $\frac{8}{9}$ \\
\hline (22) $\mathrm{Rad}$ & $\begin{array}{l}\text { 始 } \\
\text { 終 } \\
\text { 差 }\end{array}$ & $\begin{array}{r}24.9 \\
15.7 \\
-\quad 9.2\end{array}$ & $\begin{array}{r}15.4 \\
8.1 \\
-\quad 7.3\end{array}$ & $\begin{array}{r}18.3 \\
9.9 \\
-\quad 8.4\end{array}$ & $\begin{array}{l}0 \\
6.5\end{array}$ & $\begin{array}{l}0 \\
2.0\end{array}$ & $\frac{5}{9}$ \\
\hline (23) RAT & $\begin{array}{l}\text { 始 } \\
\text { 終 } \\
\text { 差 }\end{array}$ & $\begin{array}{r}24.5 \\
18.0 \\
-\quad 6.5\end{array}$ & $\begin{array}{r}15.0 \\
10.3 \\
-\quad 4.7\end{array}$ & $\begin{array}{r}18.3 \\
9.8 \\
-\quad 8.5\end{array}$ & $\begin{array}{l}0 \\
5.2\end{array}$ & $\begin{array}{l}0 \\
1.6\end{array}$ & $\frac{4}{9}$ \\
\hline (24) Rat & $\begin{array}{l}\text { 始 } \\
\text { 終 } \\
\text { 差 }\end{array}$ & $\begin{array}{r}23.8 \\
15.1 \\
-\quad 8.7\end{array}$ & $\begin{array}{r}14.6 \\
7.6 \\
-\quad 7.0\end{array}$ & $\begin{array}{r}18.5 \\
9.7 \\
-8.8\end{array}$ & $\begin{array}{l}0 \\
5.5\end{array}$ & $\begin{array}{l}0 \\
2.3\end{array}$ & $\frac{4}{6}$ \\
\hline (25) RAC & $\begin{array}{l}\text { 始 } \\
\text { 終 } \\
\text { 差 }\end{array}$ & $\begin{array}{r}24.2 \\
18.2 \\
-\quad 6.0\end{array}$ & $\begin{array}{r}14.8 \\
10.7 \\
-\quad 4.1\end{array}$ & $\begin{array}{r}18.6 \\
11.5 \\
-\quad 7.1\end{array}$ & $\begin{array}{l}0 \\
5.2\end{array}$ & $\begin{array}{l}0 \\
1.2\end{array}$ & $\frac{3}{9}$ \\
\hline (26) Rac & \begin{tabular}{l|} 
始 \\
終 \\
差
\end{tabular} & $\begin{array}{r}25.2 \\
16.3 \\
-\quad 8.9\end{array}$ & $\begin{array}{r}15.8 \\
8.8 \\
-7.0\end{array}$ & $\begin{array}{r}18.0 \\
10.9 \\
-\quad 7.1\end{array}$ & $\begin{array}{l}0 \\
5.7\end{array}$ & $\begin{array}{l}0 \\
2.0\end{array}$ & $\frac{4}{6}$ \\
\hline (27) RGY & $\begin{array}{l}\text { 始 } \\
\text { 終 } \\
\text { 差 }\end{array}$ & $\begin{array}{r}25.3 \\
22.1 \\
-\quad 3.2\end{array}$ & $\begin{array}{r}15.7 \\
13.6 \\
-\quad 2.1\end{array}$ & $\begin{array}{r}18.9 \\
13.0 \\
-\quad 5.9\end{array}$ & $\begin{array}{l}0 \\
3.2\end{array}$ & $\begin{array}{l}0 \\
0\end{array}$ & 0 \\
\hline (28) Rgy & \begin{tabular}{l|} 
始 \\
終 \\
差
\end{tabular} & $\begin{array}{r}25.2 \\
18.5 \\
-6.7\end{array}$ & $\begin{array}{r}16.0 \\
11.0 \\
-\quad 5.0\end{array}$ & $\begin{array}{r}18.3 \\
11.2 \\
-\quad 7.1\end{array}$ & $\begin{array}{l}0 \\
4.1\end{array}$ & $\begin{array}{l}0 \\
1.5\end{array}$ & $\frac{4}{8}$ \\
\hline (29) RLM & $\begin{array}{l}\text { 始 } \\
\text { 終 } \\
\text { 差 }\end{array}$ & $\begin{array}{r}25.1 \\
19.2 \\
-\quad 5.9\end{array}$ & $\begin{array}{r}15.7 \\
11.2 \\
-4.5\end{array}$ & $\begin{array}{r}18.3 \\
10.4 \\
-\quad 7.9\end{array}$ & $\begin{array}{l}0 \\
5.0\end{array}$ & $\begin{array}{l}0 \\
1.8\end{array}$ & $\frac{5}{10}$ \\
\hline (30) Rlm & \begin{tabular}{l|} 
始 \\
終 \\
差
\end{tabular} & $\begin{array}{r}25.2 \\
18.7 \\
-6.5\end{array}$ & $\begin{array}{r}15.6 \\
10.4 \\
-\quad 5.2\end{array}$ & $\begin{array}{r}18.6 \\
10.5 \\
-8.1\end{array}$ & $\begin{array}{l}0 \\
5.3\end{array}$ & $\begin{array}{l}0 \\
1.7\end{array}$ & $\frac{5}{10}$ \\
\hline
\end{tabular}




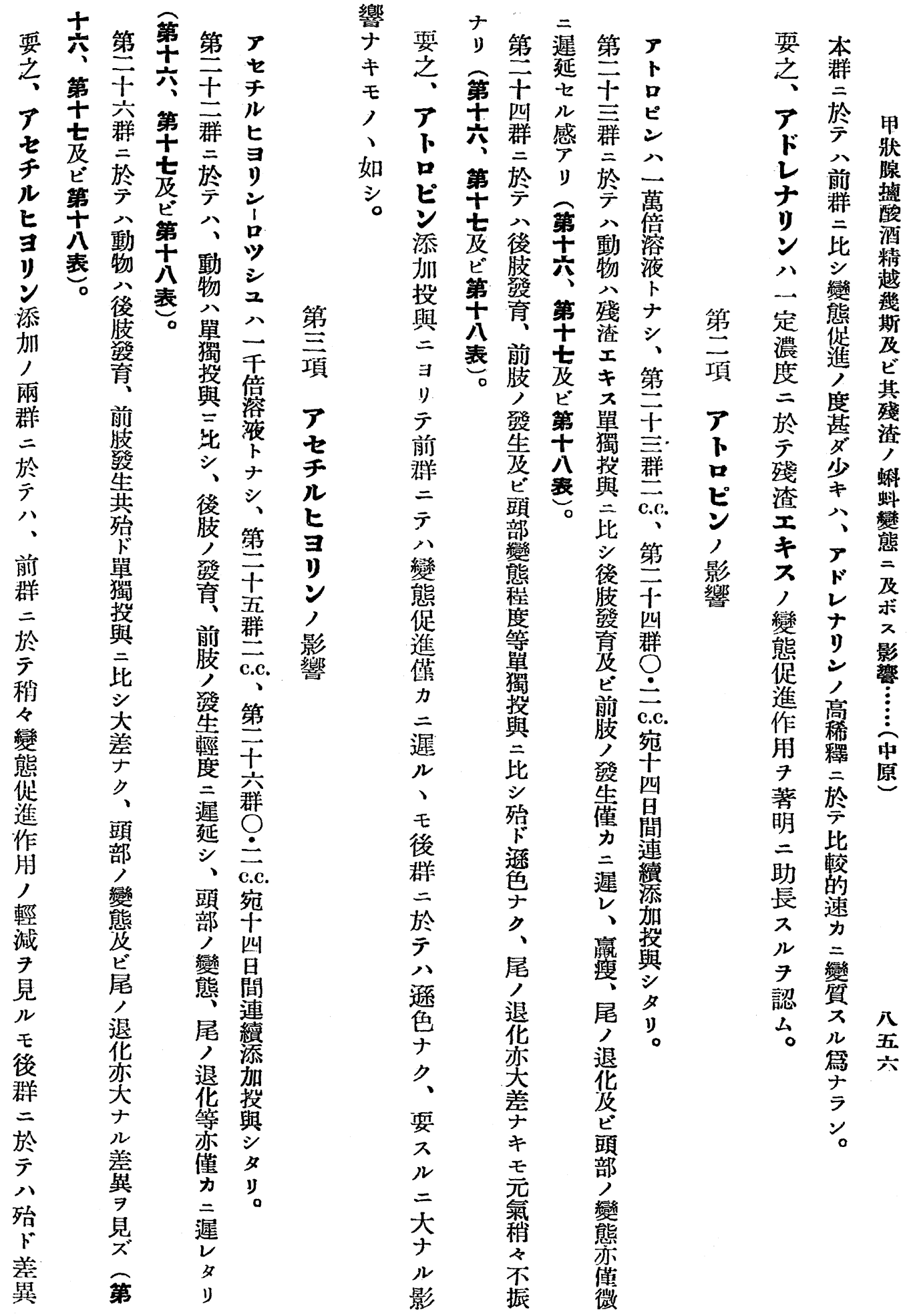




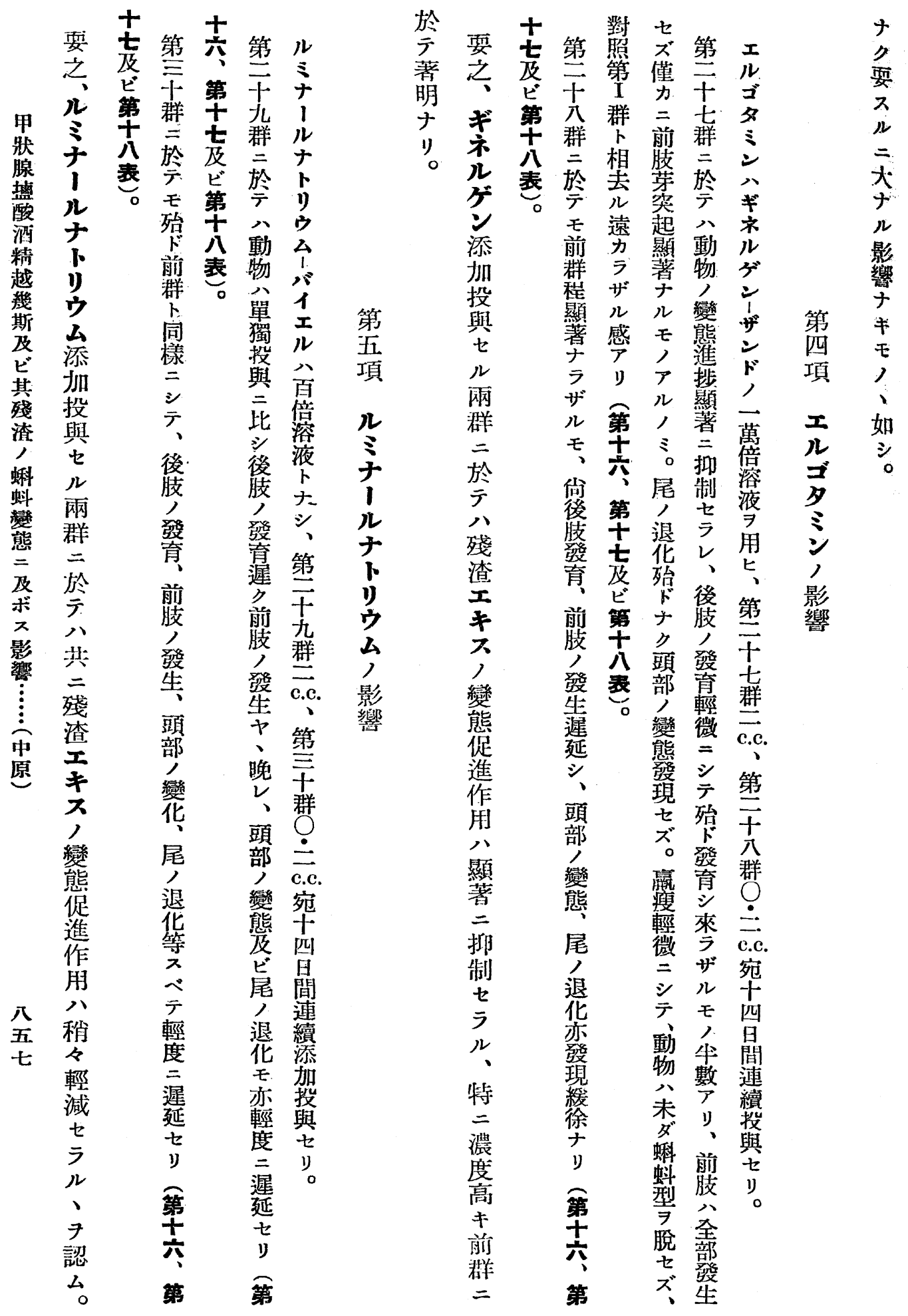




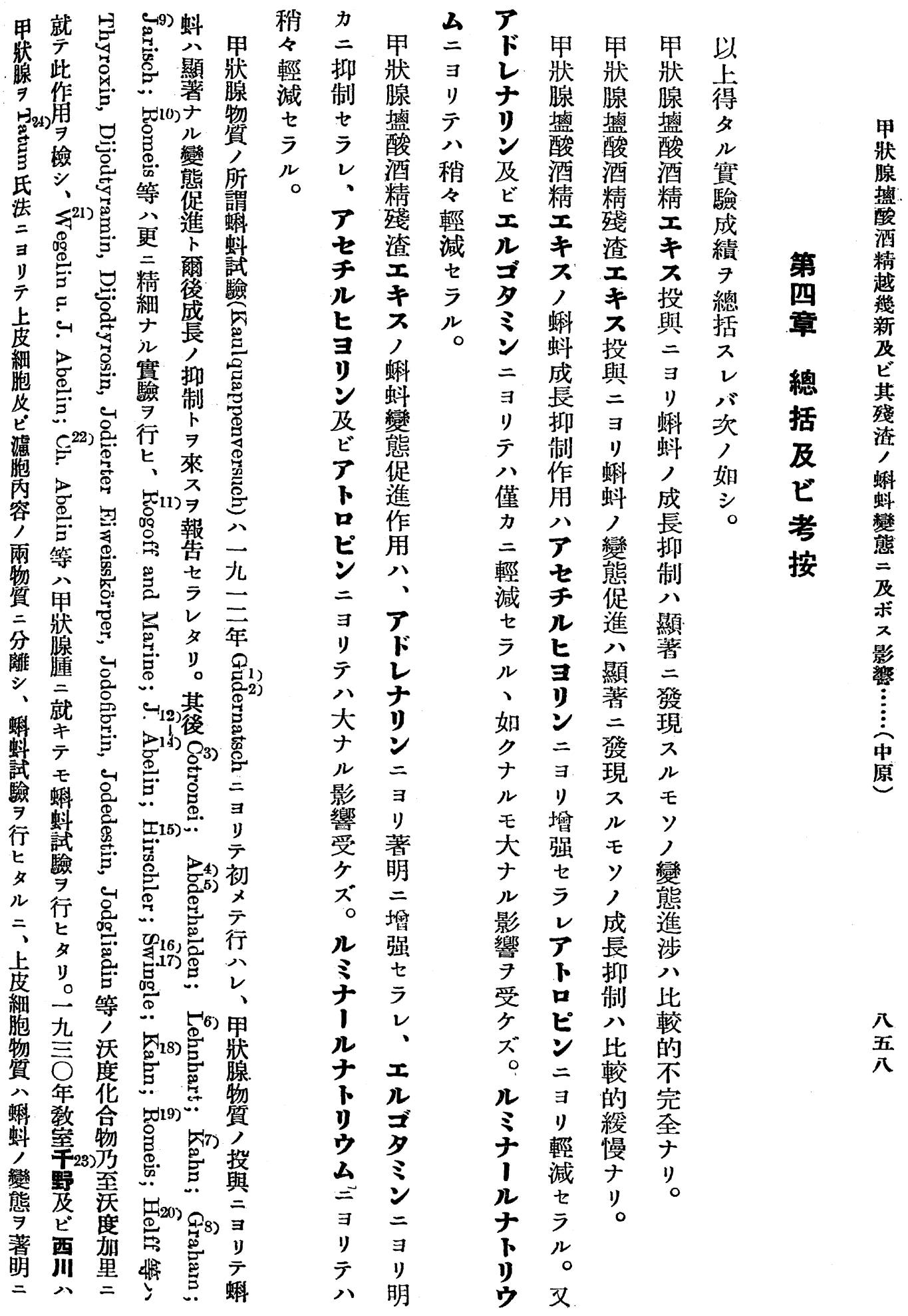


シ 八 翼 余細 シ

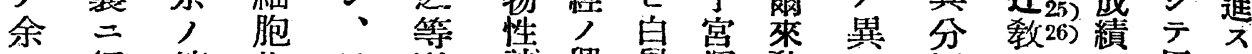

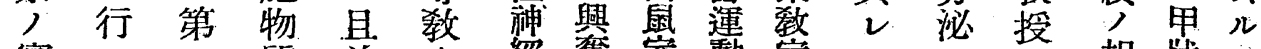

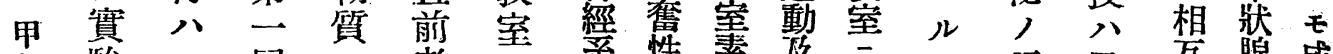
狀驗レ回二者方系性素度薪

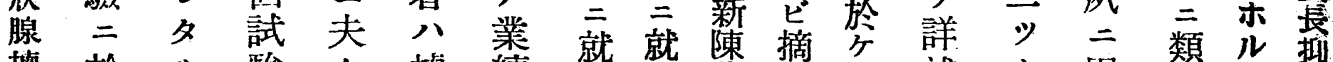

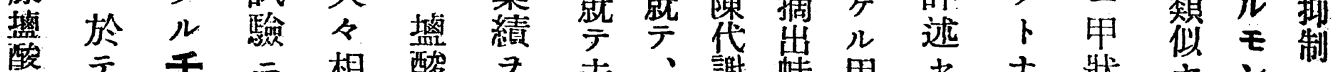

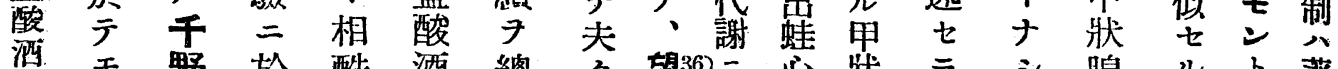

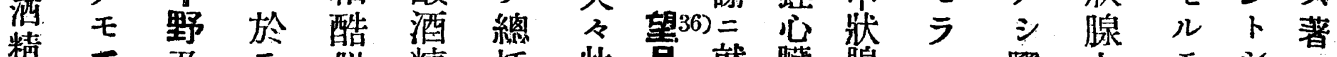

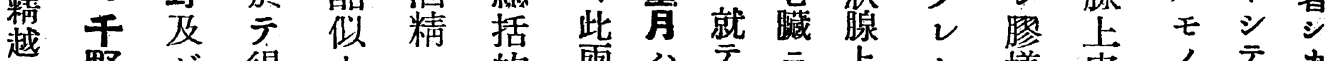
幾野 $ヒ ゙$ 得 $七$ 的兩

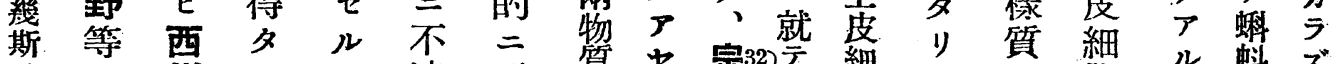

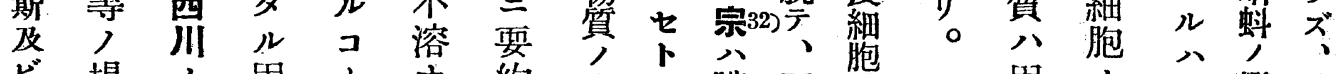

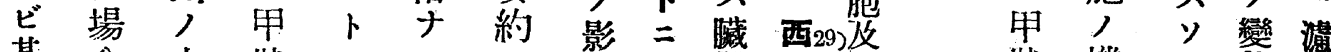

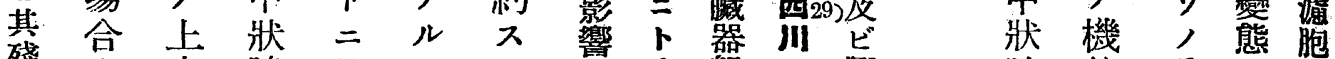

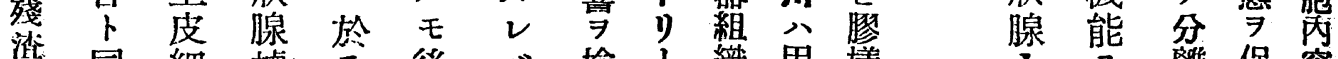

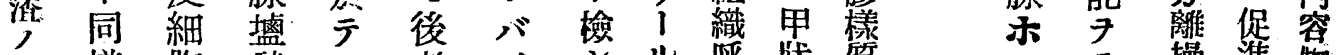

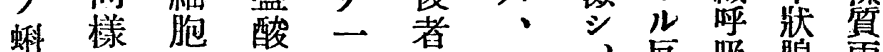
蚪网及酒致分甲专吸腺兩

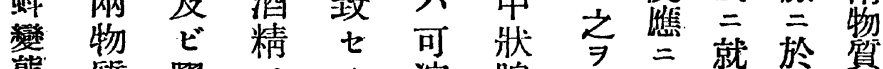

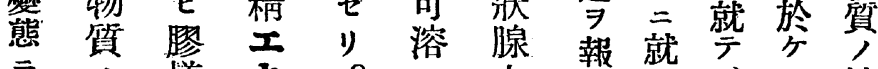

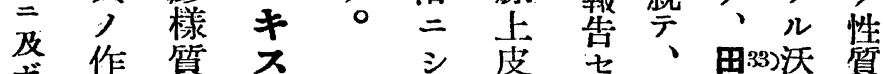

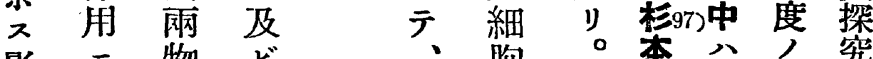

影二物 ビ 、胞口本家分究 響 或 䓄其 其物 白重布 關

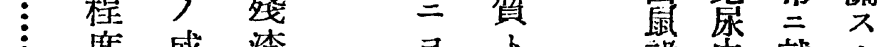

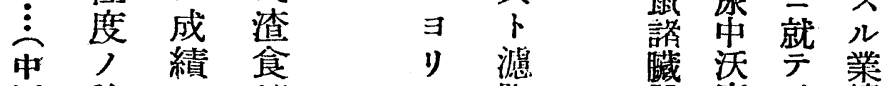

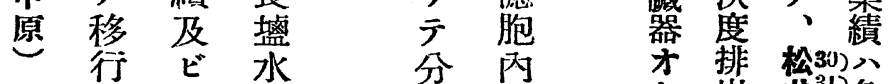
之王離容垈出 ${ }^{31}$ 多

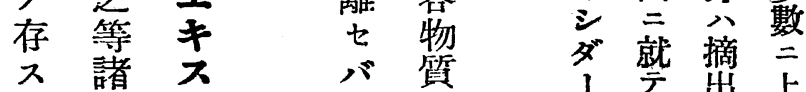
ル家, 盐即

八了同酸 千

成 - 酒 膠

其 績 沃 精 樣

八 1 度 質

五分 全 含 キ

九操 合 量 臬

作 致 二

中 $ᄌ \exists$

相ルル

腈了

互 モ 蝌

樣 生

二八 蚪

幾ナ試

分り 驗

混 而 績

質 理

二 的

其 性:

殘 質

查 全

名唯摘 上

ぜ 、出上

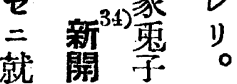

京宾 千 27

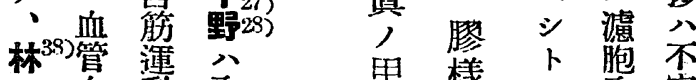

ル 分操進 物

モ千作不質

ンテ、祭 物 與

原 (一) 沙 貿

料、互上り

夕膠三皮成

ル 椂 或 細 長

モ、買 度 胞

上形占含㩆

細及

胞 ビ 澼長發

內 其 分障 現

二, 得碍 $ᄌ$

会貯 ザ

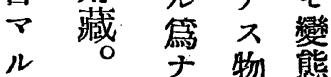

異(二) ル筫隻

電盖動 蚠

解 性白泌

䓄貿 鼠諸

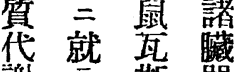

謝 示 築

就克35)詂 織

、屋家像

八

上 相

传393植 兔 摘

山物血哃

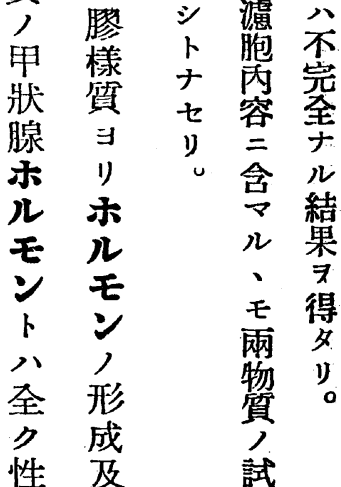




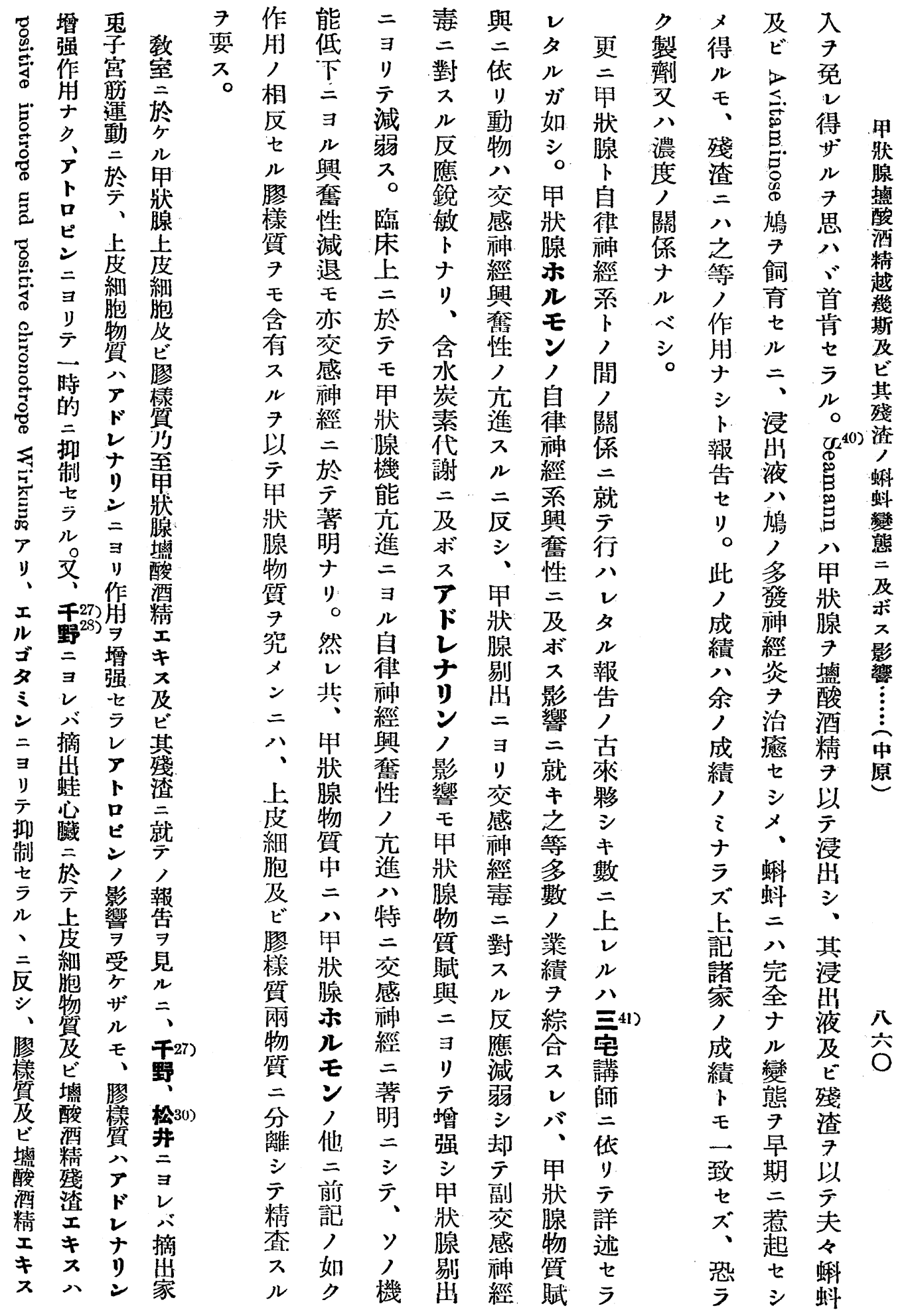




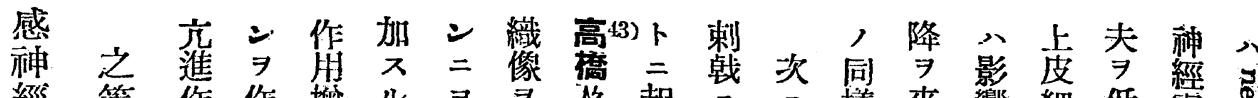

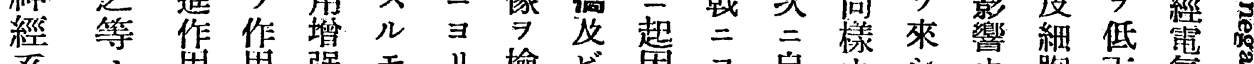
系 つ 甲 興績 抑シ、、量減報松ル影神報アキモキき

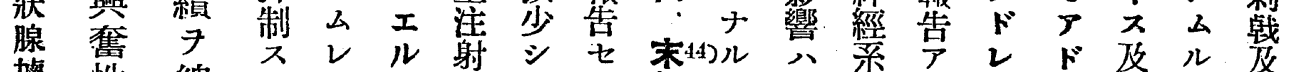
盐 性 總

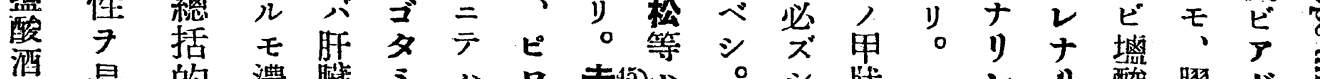

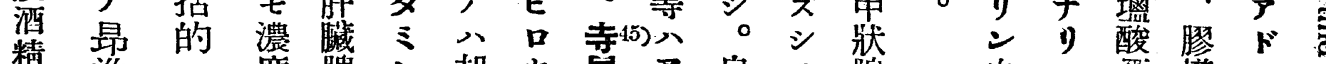
越進 耍底望

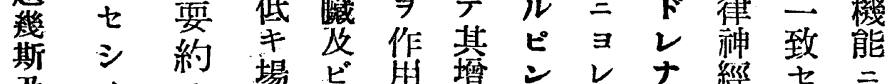

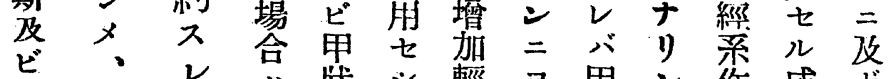

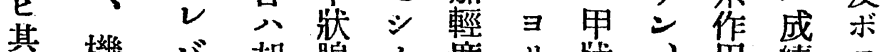

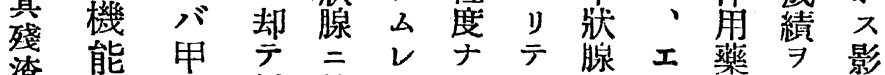

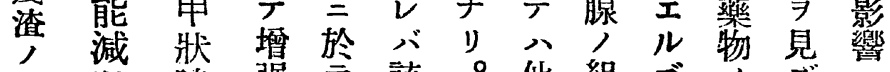
蝌退腺强テ該。他組ゴ, ズ=

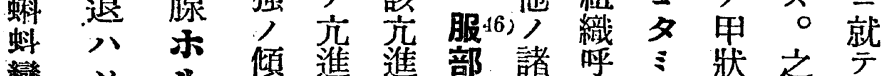

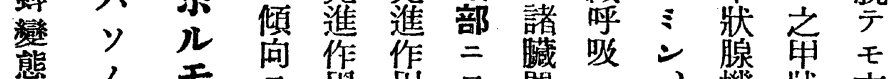

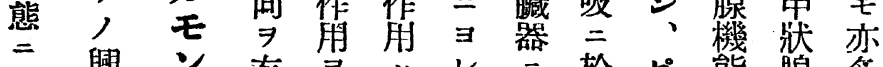

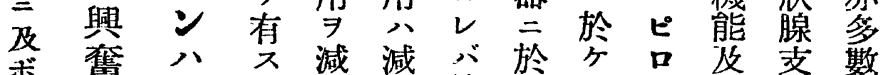

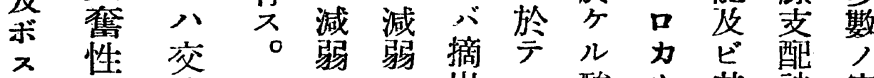
影 $\ni$ 感芯出公酸ル其神實 䇾 低 神 ル

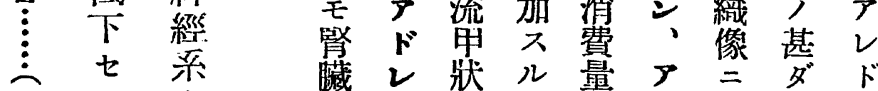
中

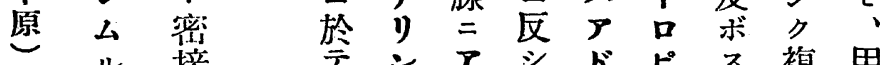

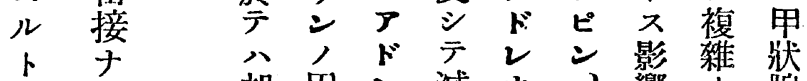
共ル却甲レ減ナ、響想腺

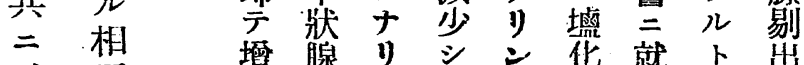

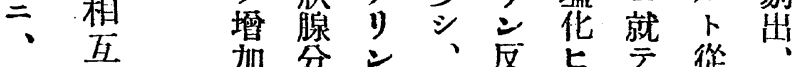

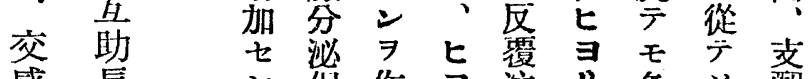
感長 シ 促作寻注り多ソ配 神作

八 經 用 メ隻角り射等數切貝

ピ 用シ シ ヨ

六, リ

一 甲 $\bar{~}$

狀 甲

腺 狀

機 腺

能 機

二 能

對充

ス 進

ル ハ

力制

ルセバテ萻注り刺切

反 交

之 $v$ 出少 $三$ 敎操文 八、液量增儿室作, 濃 $>>$ 注加動三同 度七組射シ物於甚神 高チ織 ヨア單名經 合 寻竞

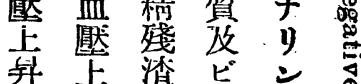
作杽工媲作 捅㤰 影分 八酒就 響 墳 家: エ ナ强鬼 $キ$ 宙 キシ方公、点 口樣減走細吉 カ 質 少神笣 ル范、經物り ピ 呼算?

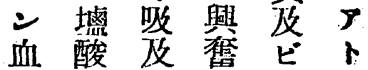

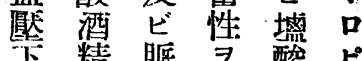
降精 膑 $\exists$ 酸 ピ 作 キ 數進 精 二 用 ス 型七殘 $\exists$ $\exists$ 八加 $三$ 㴡り 樰家並. $工$ 厂 强鬼三厂キ阻 ス㮩ドス止 其體㷉レ六さ 他塯势り感儿。 宗32) 加 7 來 作 經 古35)

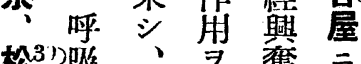

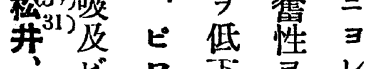
田33)胍力七茫六 中搏 ル 進家 望36減 ビ合 セ 象 月 少血又 又嬮 並欇 佐39) '二

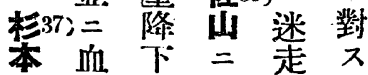
本血筷 作 $\exists$ 走

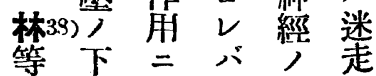




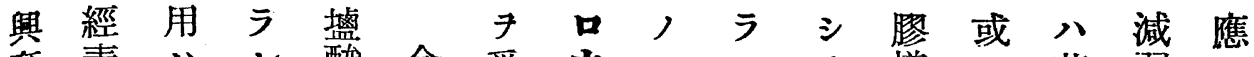
奪毒八レ酸余受カ、レタ樣心甚弱八

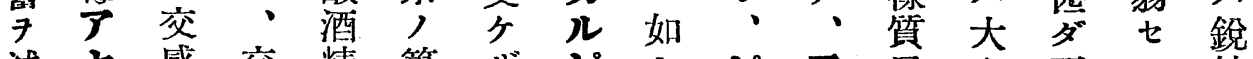

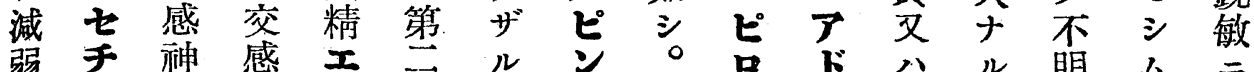

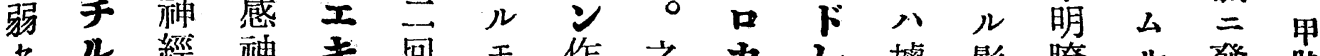

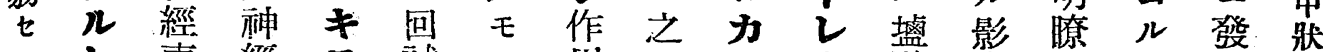
シ七毒經 ス試, 用二ルナ酸響ニコ現腺

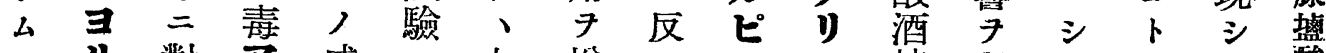

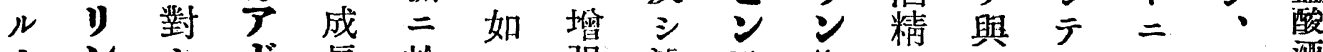

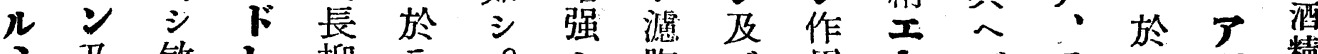

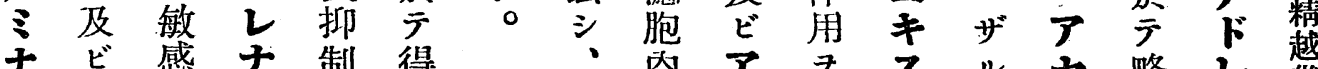
ナビ 感子制得・㐫

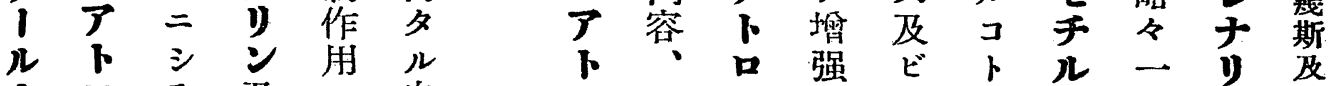

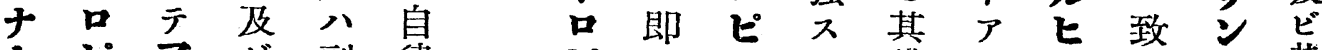

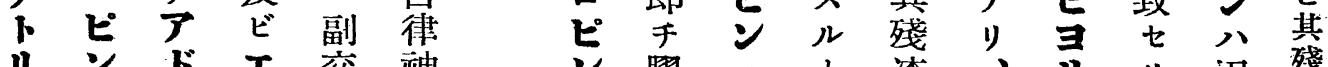

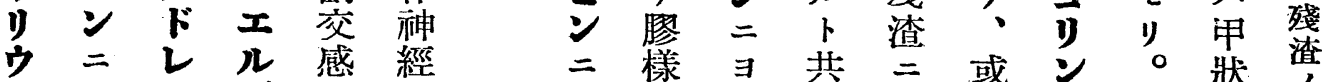

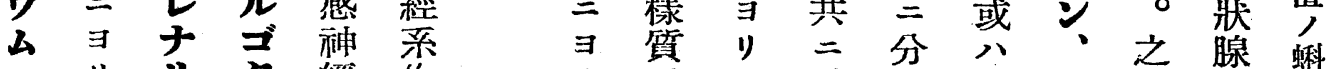
ニリリ 少 經 $\exists テ ン ミ$ 毒用 リ $ハ=\boldsymbol{V}=$ 藥 テ大 $\exists=$ 銳 物 八ナリ ヨ 敏ノ

兩ル著り二影 者影 明 テ シ 響 基響二大 成 二 增ナナ・績 輕受强ルアハ 度ヶ、影を之 ニザエ響 チ等 減几ル光諸 弱 結 ચ゙ 受 七家 七果夕夕少 ラ ミザリ成 レ來ンルン 績 夕 $九 二=$ 二 り 少明、檑 合 交为其强 致 感二殘 及輕查尗ル ビ減 エ王 副七キピノ 交ラ 感レ, 綡 神副戀態当 テ 經交 促減甲 系感進 弱 狀 神 作 $七$ 腺

リテテッ濃ピ二機蝴 テ及心ドト度品反能戀 抑八不

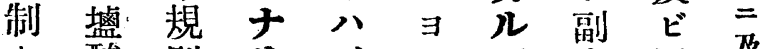
七酸則り、り ピ 交甲 及 ラ酒ナり上テン 感狀 ル精ル二友反神腺影 、工成当細 對 $ア$ 經 ホ 警 モキ績 リ胞ノト毒ル ドニ 來 ソ キ キ 結

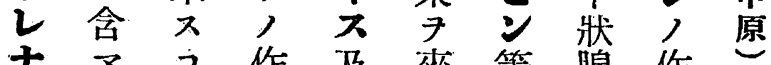
リルコ作 及來等腺作

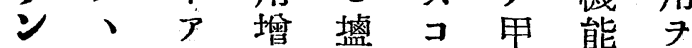
及有儿强酸卜狀及苋 ビ 效モを酒ア腺ビ進 エ物、ラ精り機甲 七 ル質要 $v$ 殘。能狀 シ

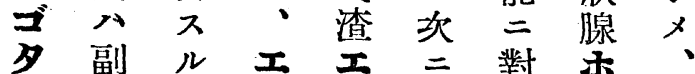

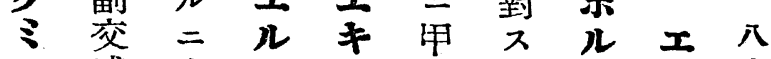

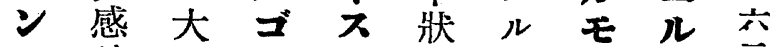

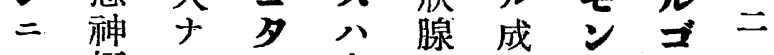
$\exists$ 經ルミ交物績, 夕 リ $フ$ 影 ン 感質 $ハ$ 作ミ テ興響二秆 $キ$ 或用 八舊 $コ$ 經上小二小 大七受り系皮 一對此 ナジテテ細汪 ス, ルメザ抑興胞 $ォ ル$ 兩 影・儿制舊及负反者 響とモセ七ビキ應 


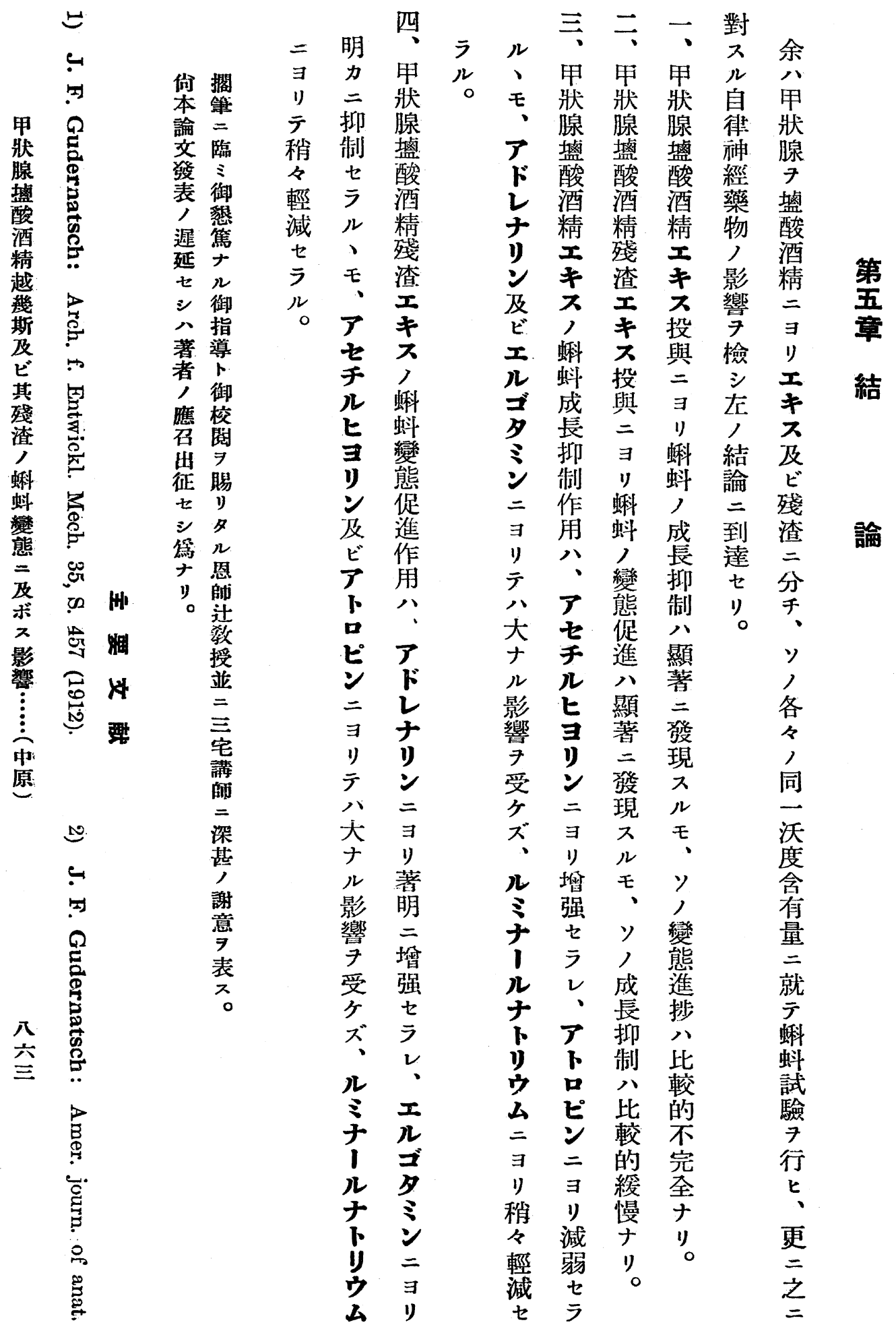




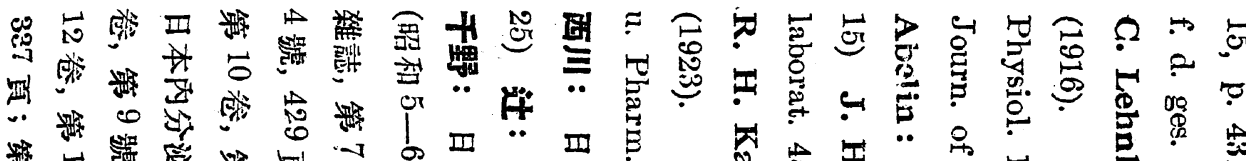

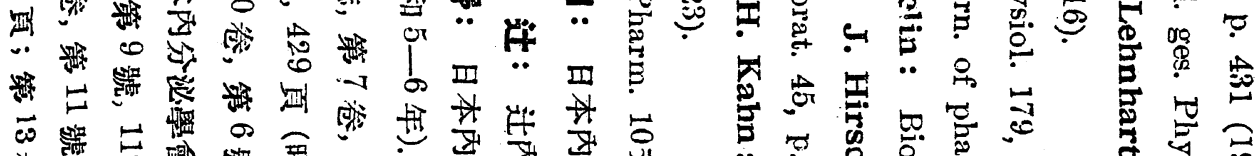

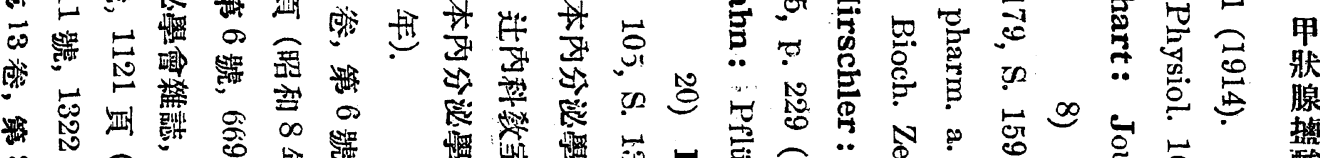

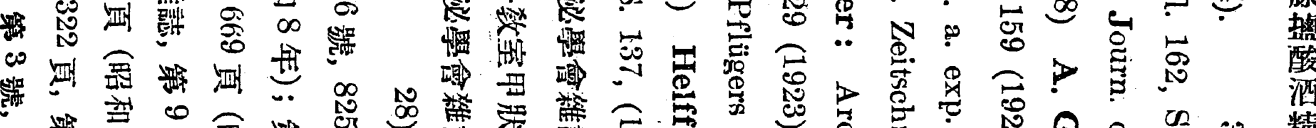

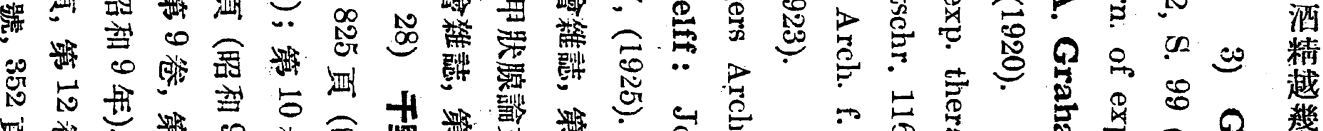

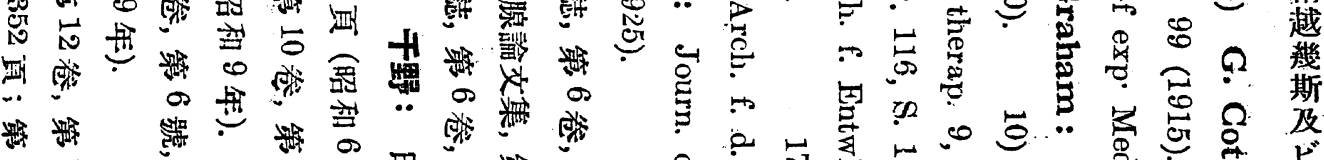

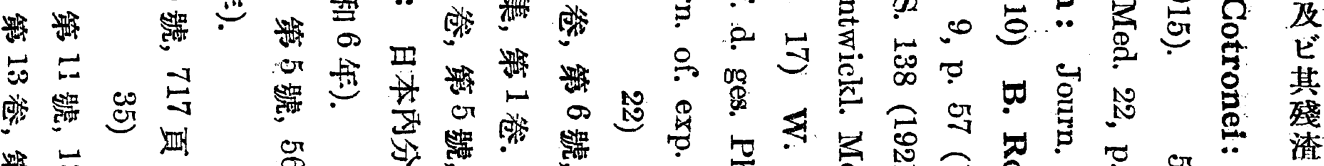
路

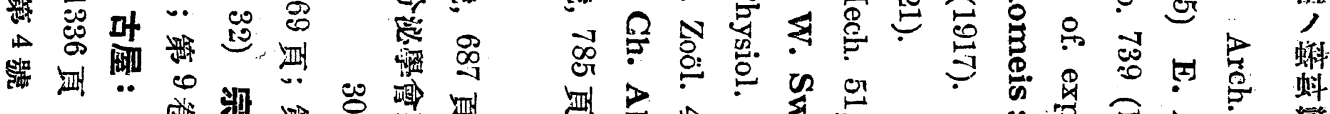

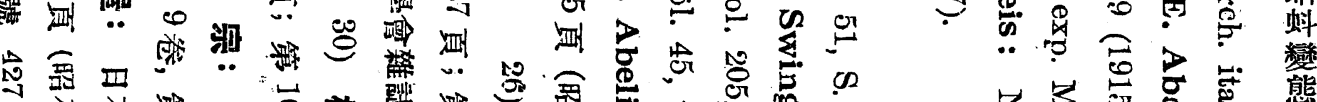

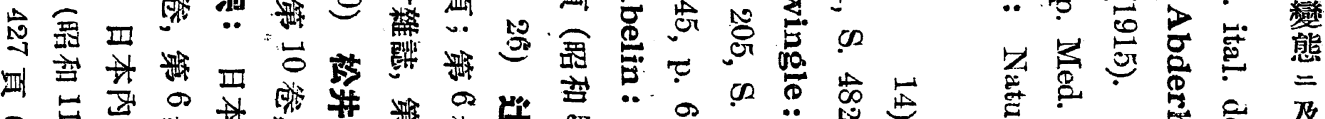

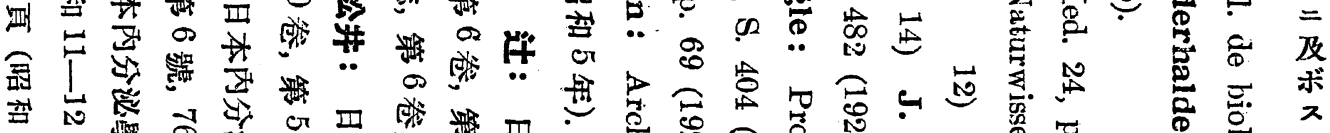

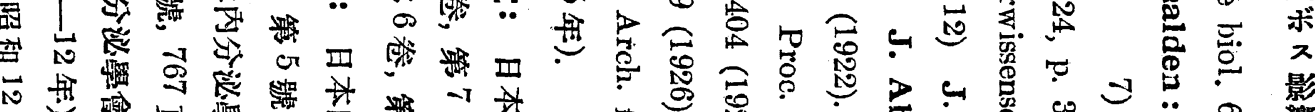

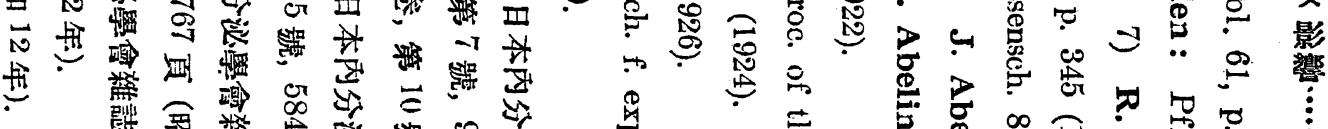

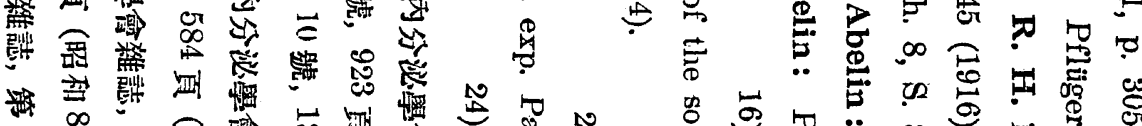

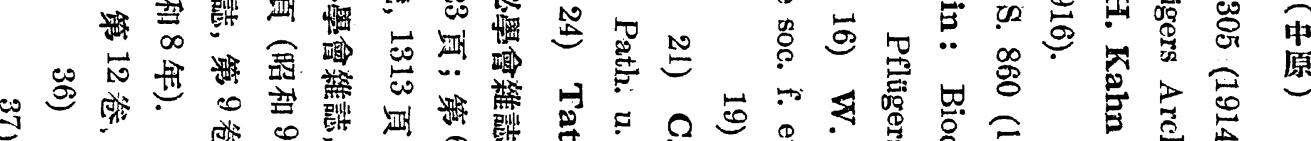

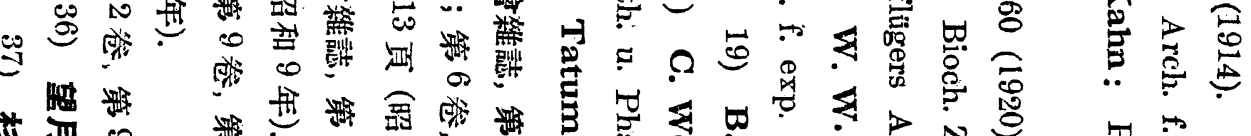

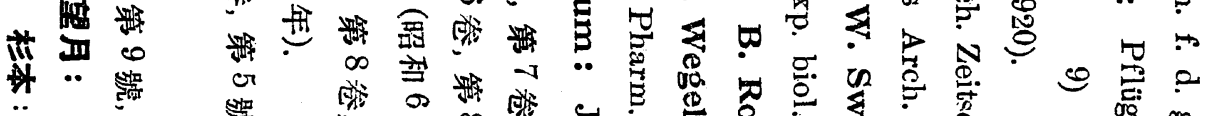

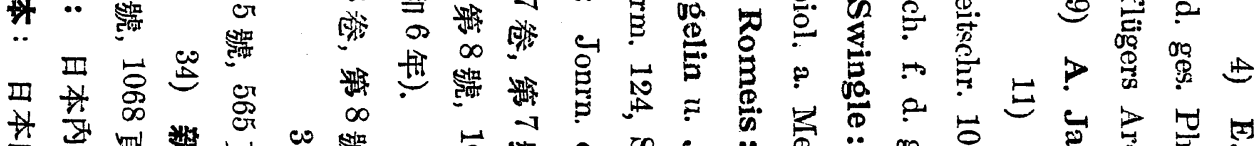

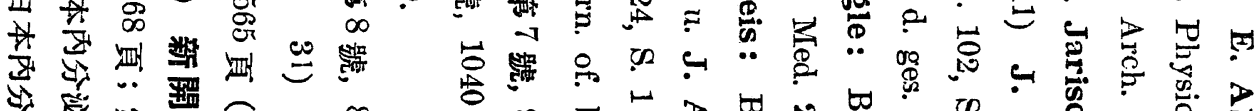

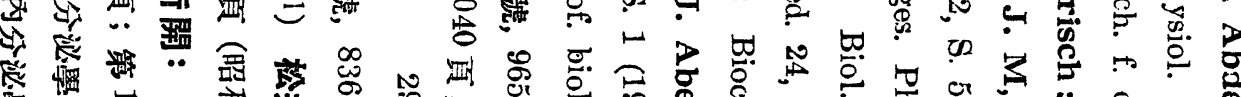

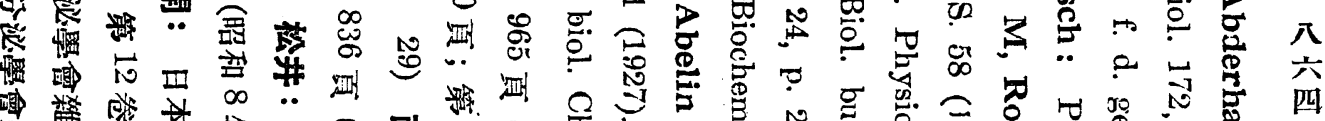

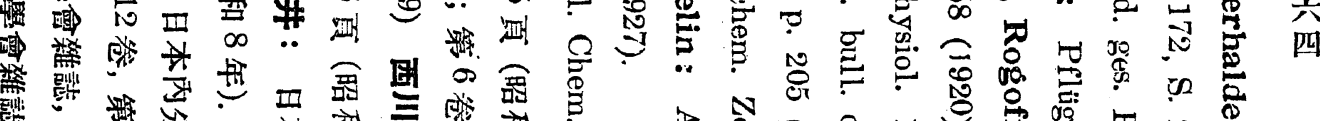

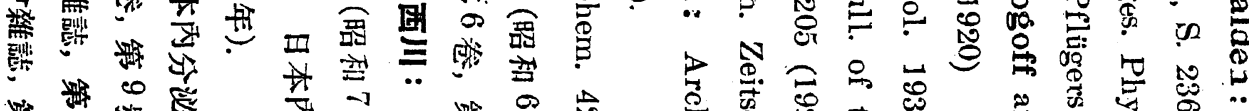

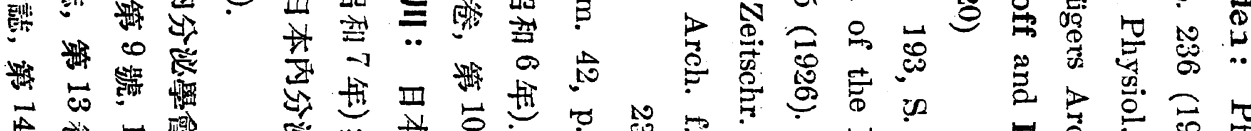

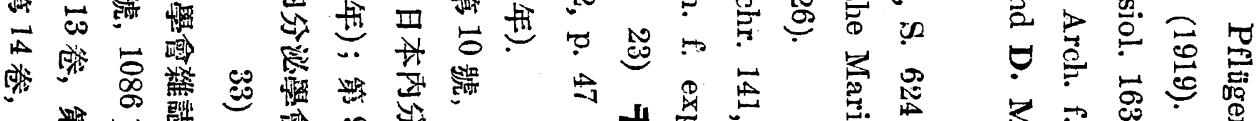

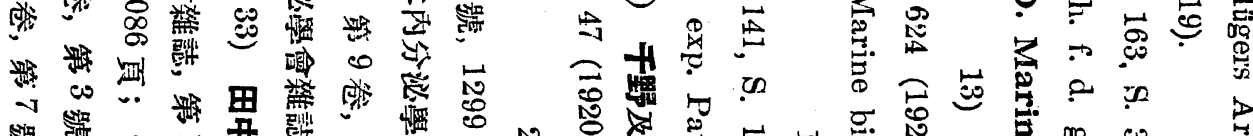

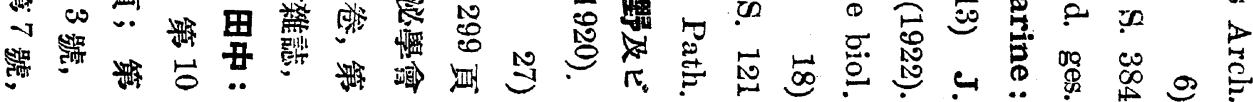




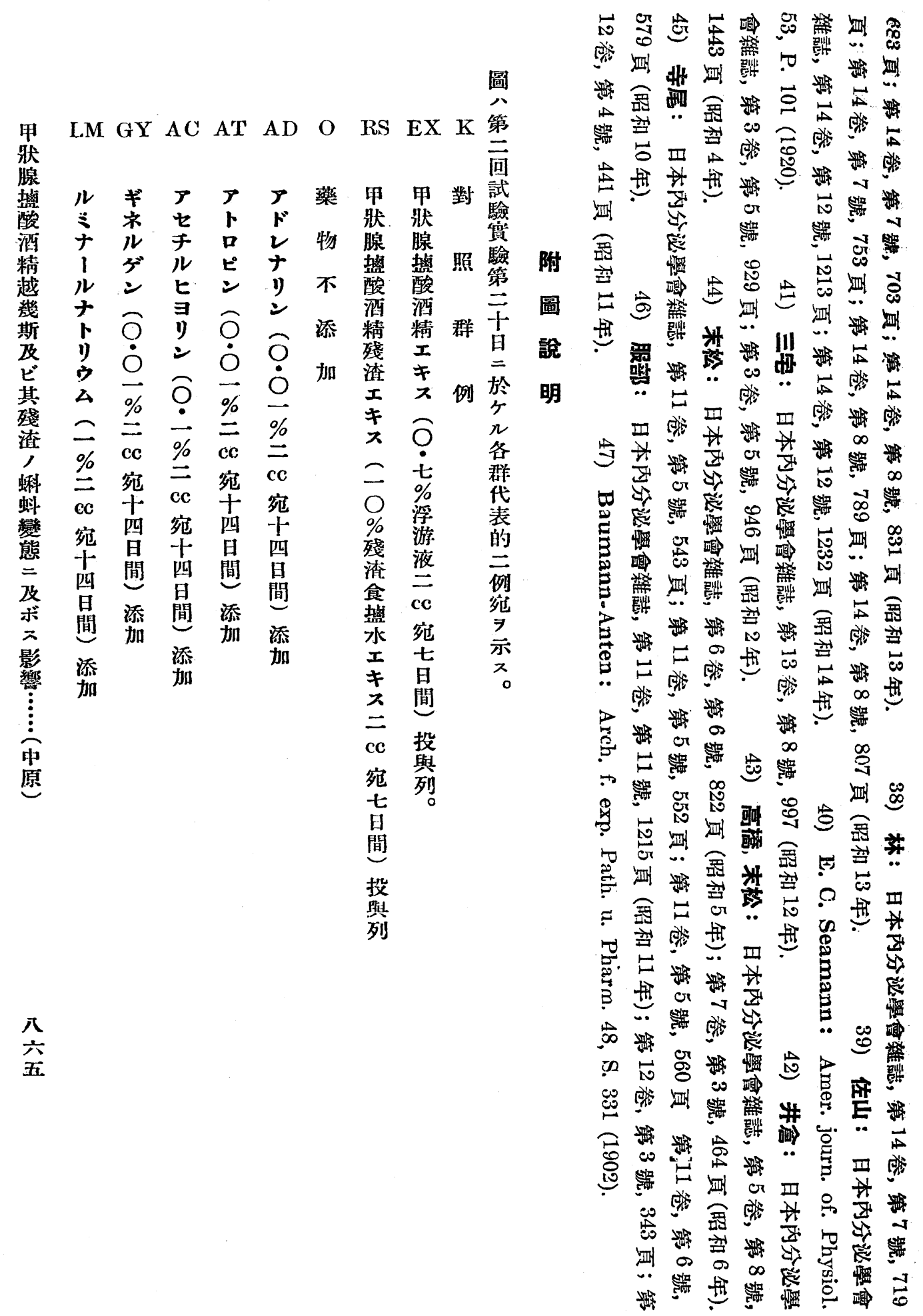




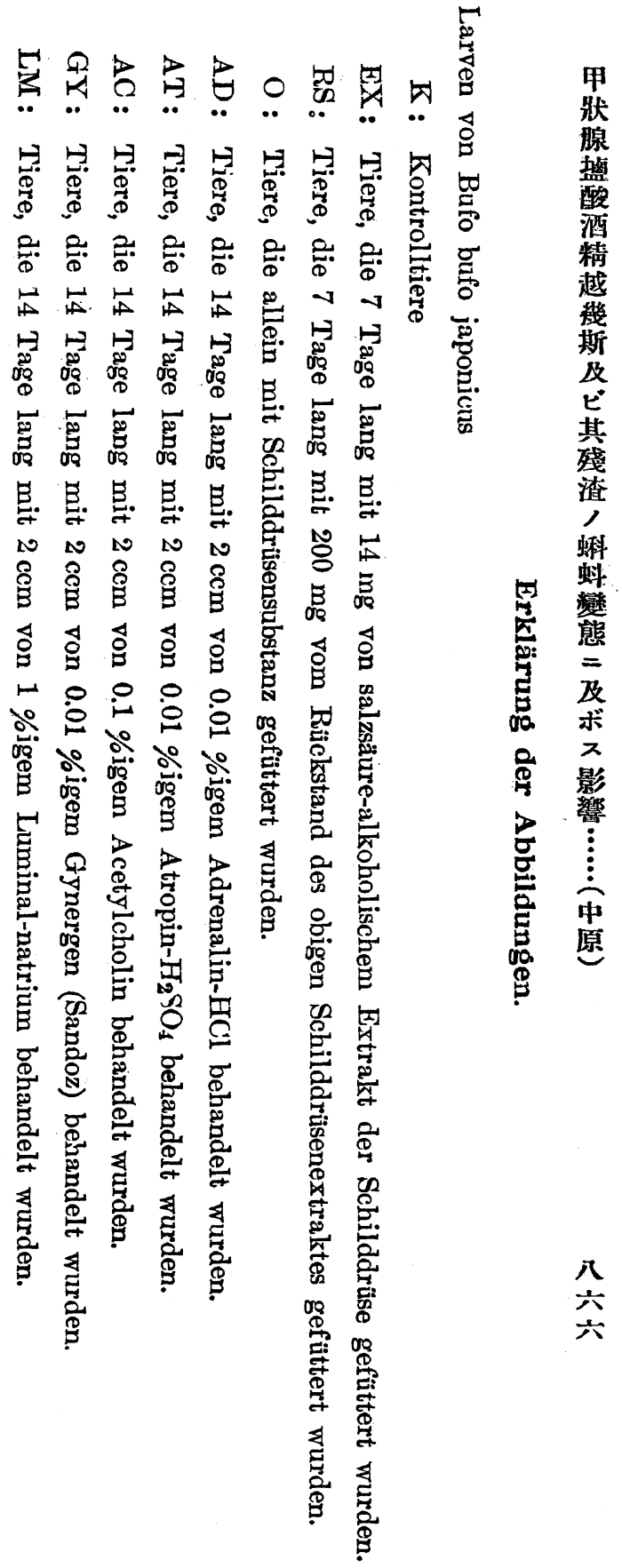




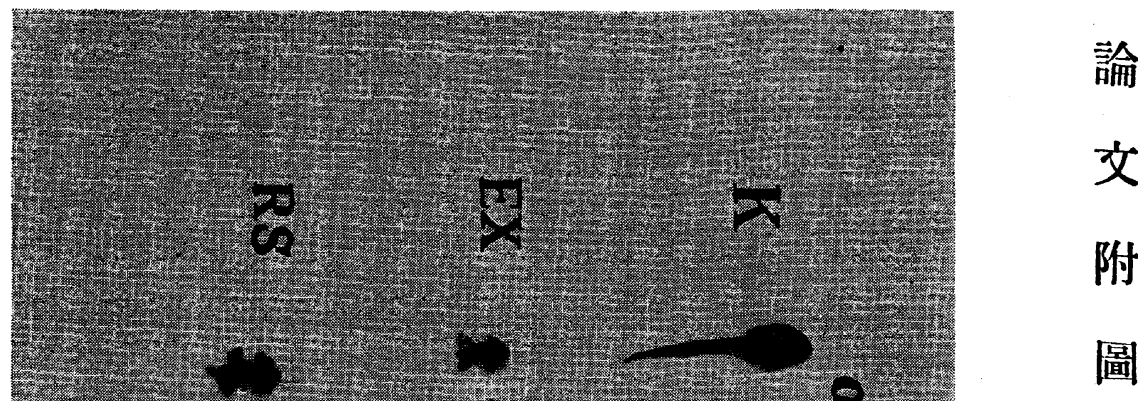

詥侖

交

附

圖 
Wirkung des Rückstandes des salzsäurealkoholischen Extraktes ist stärker als die des alkoholischen.

(Autoreferat)

\title{
Die Wirkung des salzsäurealkoholischen Extraktes der Schilddrüse und des Rückstandes auf die Amphibienmetamorphose sowie der Einfluss der verschiedenen Nervengifte darauf. (Kaulquappenversuch I. Mitt.)
}

\author{
Von \\ Dr. W. Nakahara.
}

(Aus der I. Med. Klinik der Kaiserl. Universität zu Kyoto in Japan.

Direktor: Prof. Dr. K. Tsuji.)

Chino und Nishikawa in unserer Klinik haben in dieser Zeitschrift (Bd. 6., H. 6.) über die Wirkung der Epithelzellen- und Kolloidsubstanz der Schilddrüse auf die Larvenentwicklung interessante Resultate mitgeteilt.

Der Verfasser hat die Wirkung des. salzsäure-alkoholischen Extraktes der Rinderschilddrüse und des Rückstandes auf die Metamorphose der Larven nach Gudernatsch'schem Verfahren untersucht und weiter den Einfluss der verschiedenen autonomen Nervengifte, nämlich des Adrenalins, Atropins, Acetylcholins, Ergotamins und Luminalnatriums wiederum auf diese Wirkung beobachtet. Als Versuchstiere wurden Larven von Bufo bufo japonicus gerade vor dem Durchloruch der Hinterbeine verwandt., Sie wurden mit gekochten Kartoffeln ernährt.

Die Resultate waren wie folgt.

1) Beide Schilddrüsensubstanzen d. h. der salzsäurealkoholische Extrakt der Schilddrüse und der Rüekstand desselben beschleunigte die Metamorphose der Kaulquappen und verzögerte bzw. unterdrückte ihr weiteres Wachstum. 
2) Bei der Extraktsubstanzfütterung traten die Rückbildungserscheinungen am Schwanz früher auf und sehritten schneller und stärker fort als bei der Rüekstandsubstanzfütterung. Die Metamorphose der Larven war hierbei weniger vollkommen als in letzterem Falle und der Durchbruch der Vorderbeine fand oft zuerst halbseitig statt.

3) Bei der Fütterung mit der Rückstandsubstanz war die Förderung der Metamorphose sehr auffallend, das. Wachstum wurde in leichtem Grade gehemmt.

4) Adrenalin veranlasste eine geringe Abschwächung der durch die Extraktsubstanz bewirkten Wachstumshemmung und eine deutliche Verstärkung der durch die Rückstandsubstanz bewirkten Beschleunigung der Metamorphose.

5) Atropin schwächte die hemmende Wirkung der Extraktsubstanz auf das Larvenwachstum in leichtem Grade ab, und rief keine Veränderung der entwicklungbeschleunigenden Wirkung beider Substanzen hervor.

6) Durch Acetylcholinzusatz kam die Wachstumshemmung des Extraktstoffes stärker zur Geltung.

7) Ergotamin schwächte die wachstumhemmende Wirkung der Extraktsubstanz leicht und die metamorphosebeschleunigende Wirkung, der Rückstandstoffes sehr stark.

8) Luminalnatrium schwächte die durch beide Substanzen bew-. irkte Beschleunigung der Metamorphose ebenso wie die durch die Extraktsubstanz erzeugte Wachstumshemmung. (Autoreferat)

\title{
Die Wirkung des thyreotropen Wirkstoffes der Hypophyse auf die Amphibienmetamorphose und der Einfluss verschiedener Nervengifte darauf. (Kaulquappenversuch II. Mitt.)
}

\author{
Von \\ Dr. W. Nakahara.
}

(Aus der I. Med. Klinik der Kaiser1. Universität zu Kyoto in Japan.

Direktor: Prof. Dr. K. Tsuji:) 